\title{
Fantastic in novel "Shari mosiqare Spiekan" by Bextiar Ali
}

\author{
Abdulla M. Amin ${ }^{1}$ \\ Azad Mohammed Saeed ${ }^{2}$
}

Received: Mar 07, 2018Reviewed: Apr 07, 2018

Accepted: Apr15, 2018

\begin{abstract}
In the Kurdish literature specially in the Kurdish novel, fantastic is not so old, also there is not too many fantastic novel writers in the Kurdish literature, fantastic is also known as a free kind literature, it has some characteristics which can't be found in other genres, the Portuguese teziftian to dourfie mentioned all basis of art for this kind of literature in the book of " the gate to fantastic literature ", in this research we choose only one kind which is the kind of place in the novel of (Shari mosiquare Spiekan) that is written by ( Bakhtiar Ali ). It's obvious that place is one of the most basic kinds of novel and in the fantastic novel it is meant to be abnormal place. The research consists of introduction, two parts and results: The first part named under (the place of fantastic in novel) and it's divided into two sorts. In the first explains the place of fantastic theoretically, in the second explains about the place of fantastic in the novel, and in the second part practically talks about the places of fantastic novel (Shari mosiqare spiekan) and well explained, and in the last the results and the list of resources are written.
\end{abstract}

Keywords:Fantastic, Real Space, Fantastic Space, Shari Mosiqara Spiekan, Gelasi Spian, Anfal

\section{Recommended citation:}

Amin, A.M.\&Saeed, A.M., (2018). Fantastic in novel "Shari mosiqare Spiekan" by Bextiar Ali. International Journal of Kurdish Studies 4 (2), 562-579. doi: 10.21600/ ijoks.454483

\footnotetext{
${ }^{1}$ Asst. Prof., Department of Kurdish language, School of Language, Sulaimani University, Sulaimani , KRG, Iraq, E-mail: muhamad.tatani@yahoo.com

${ }^{2}$ Lecture, Department of Kurdish language, Faculty of Education, Koya University, Erbil, KRG, Iraq, Email:azad.mohammed@koyauniversity.org
} 


\section{شوينى فانتازيا له (روّمانى شارى موّسيقاره سبييهكان)ى (بهختيار على)داداد}

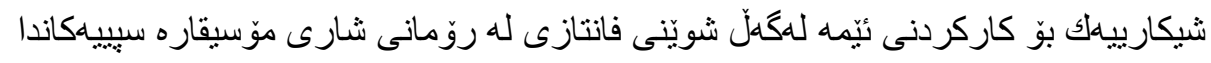

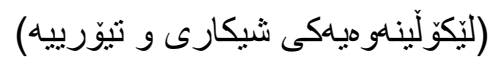

م.ئاز اد محماهد سهعيد

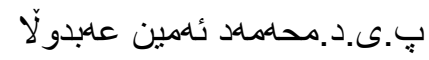

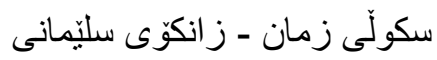

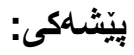

له ئهدهبى كوردى و به تايبهنى له روّمانى كورديدا، فانتازيا زوّر كوّن نيبه، هه روهها نووسهر انى روّمانى

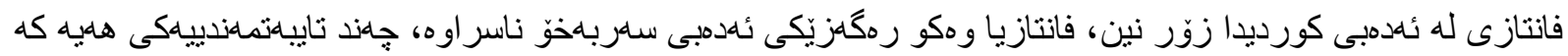

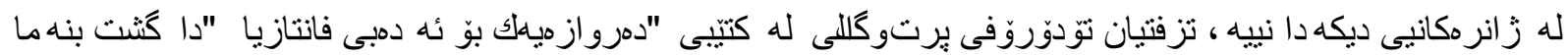

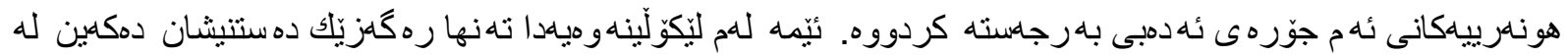

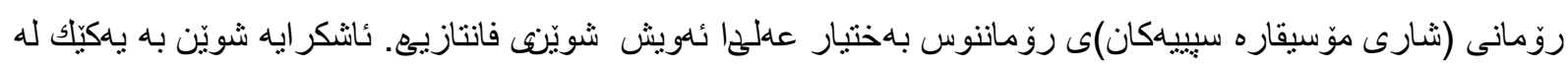

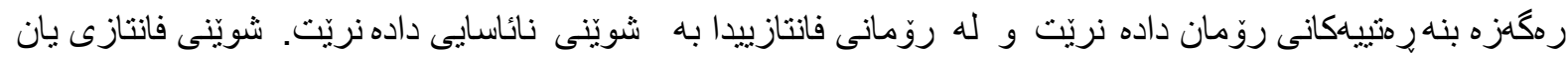

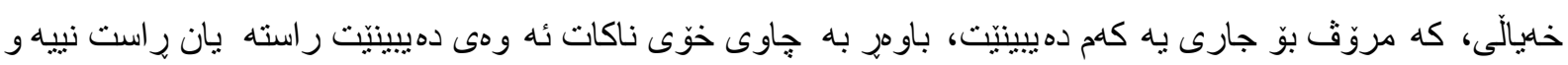

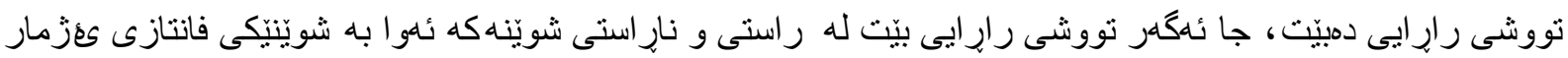
دمكريّت.

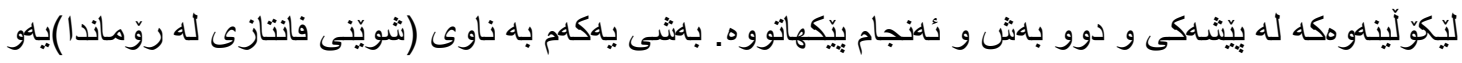

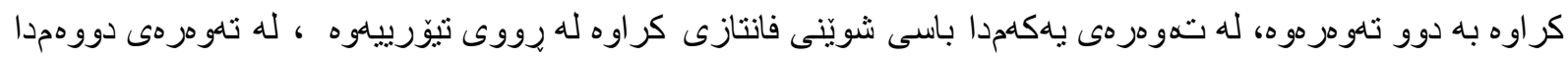

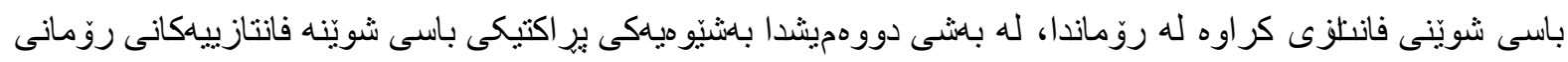

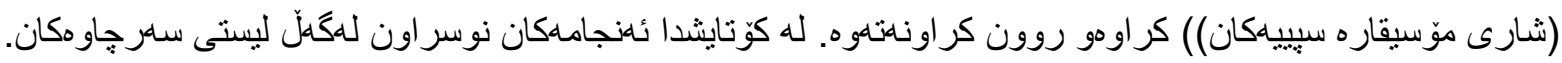

\section{باهشى ياكلمم \\ شوينى فانتازى لله رِوْماندا}

\section{تهورورى ياكلهم: شوينّى فانتازى}

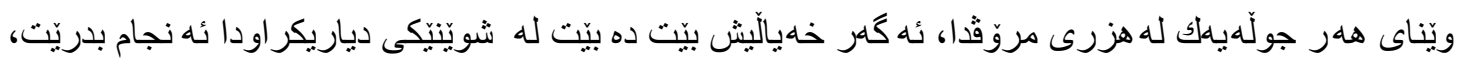

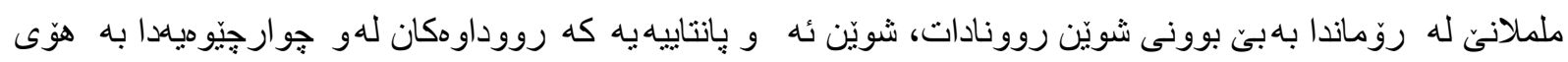

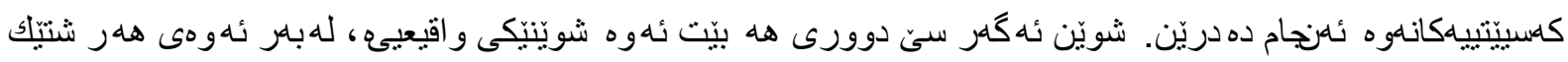

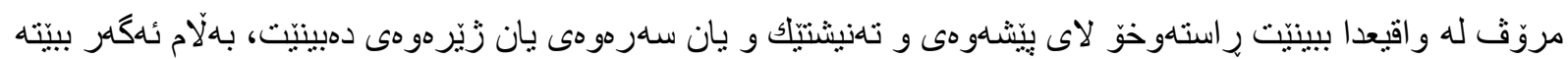

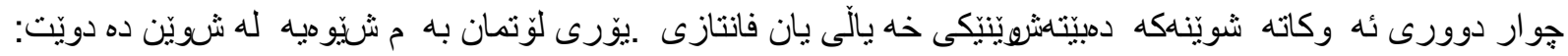

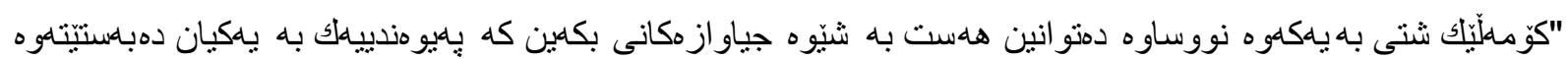




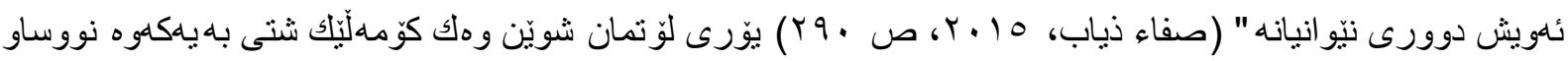

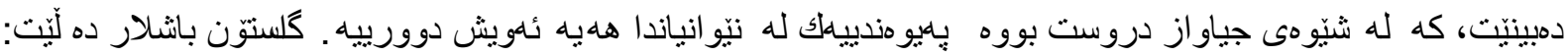

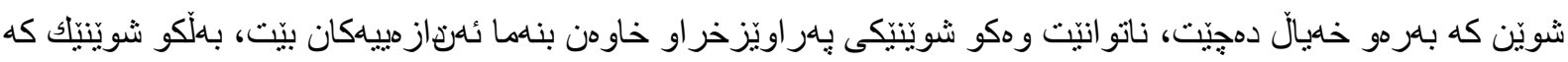

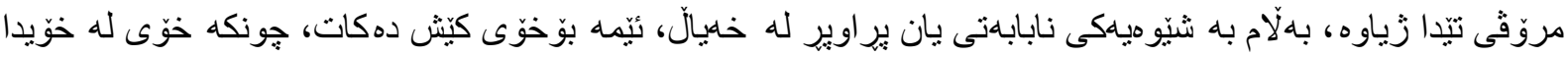

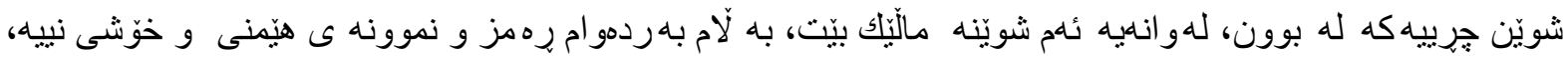

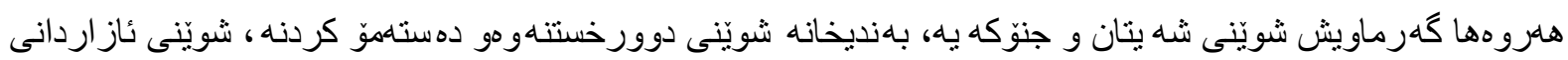

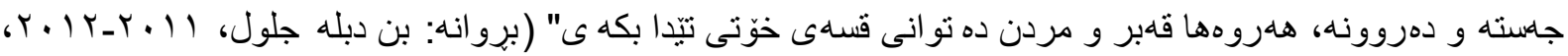

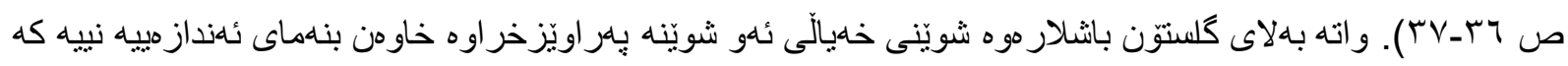

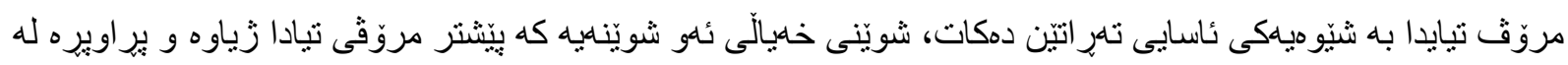

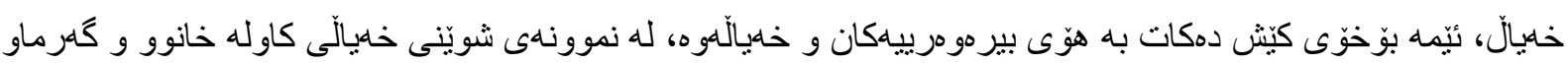

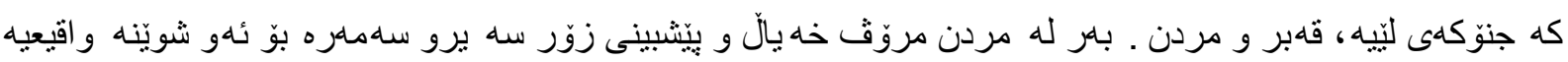

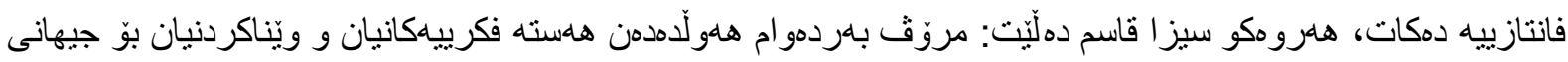

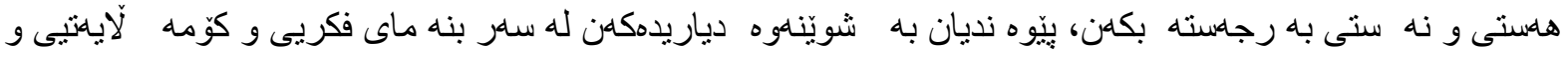

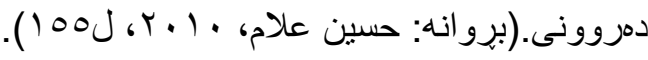

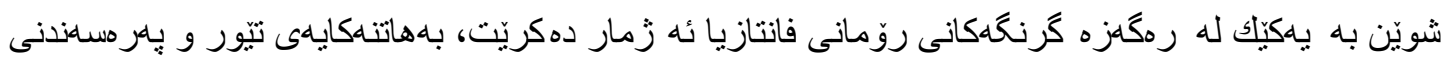

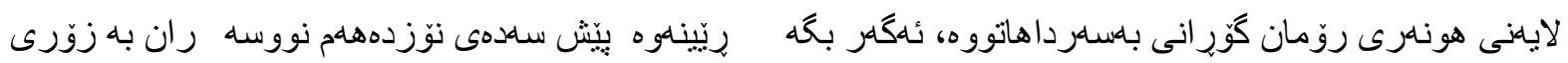

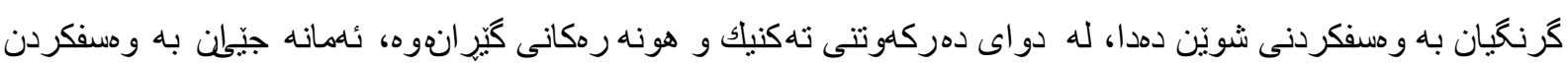

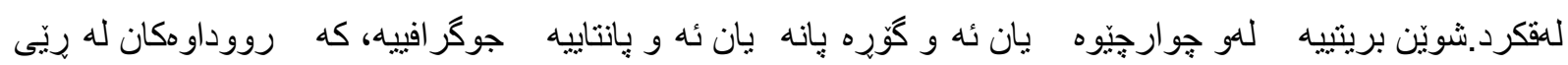

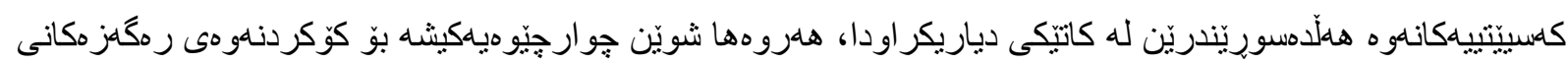

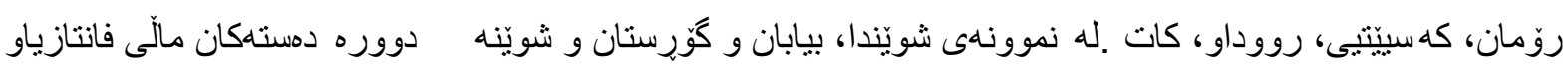

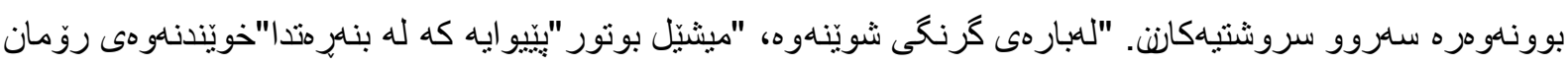

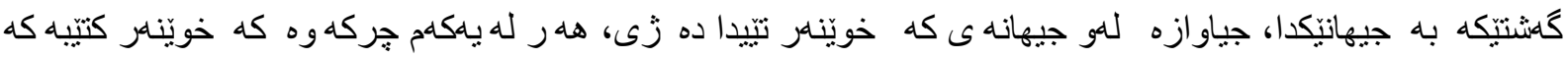

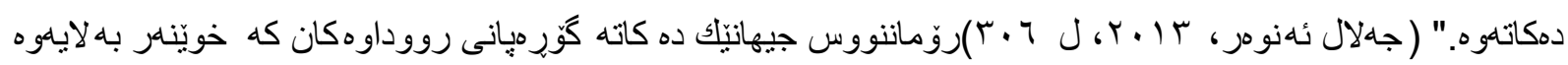

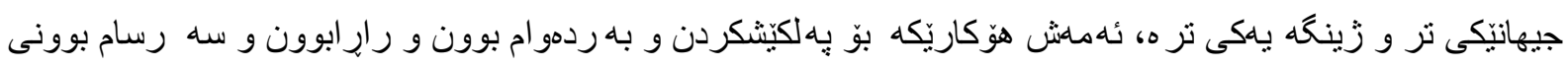

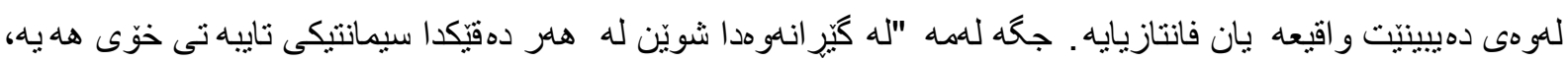

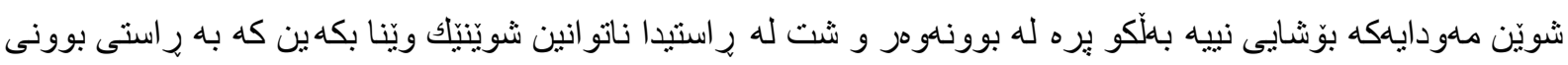

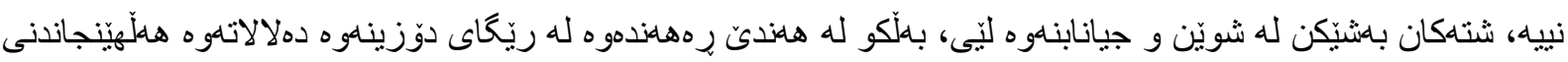

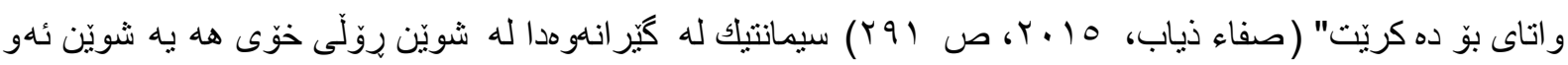

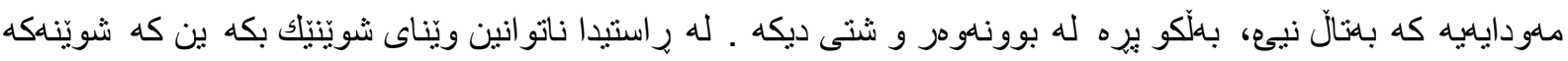

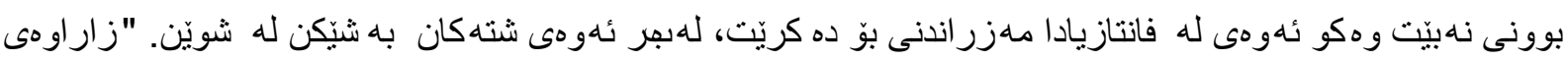
"eireaF"

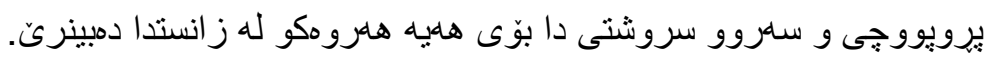

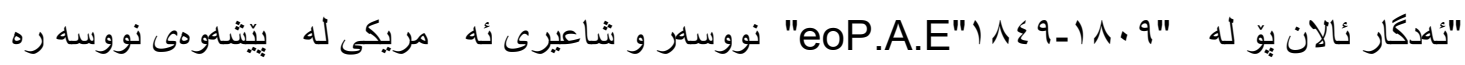

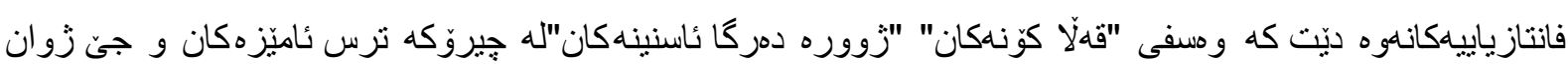




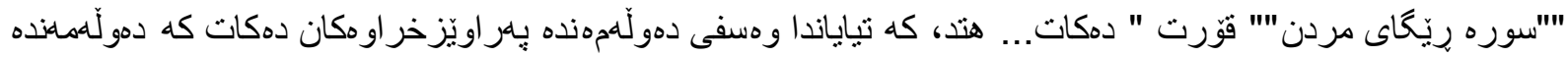

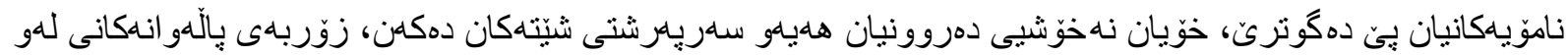

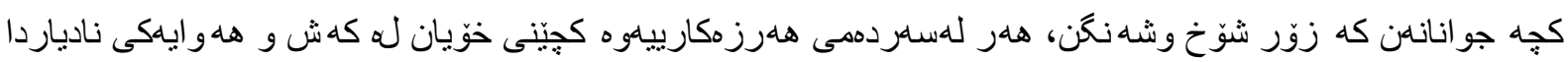

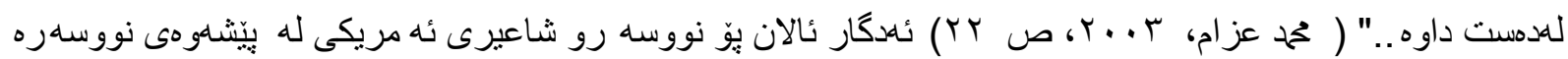

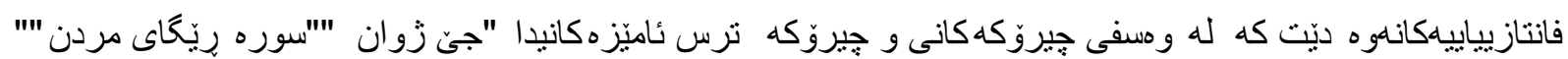

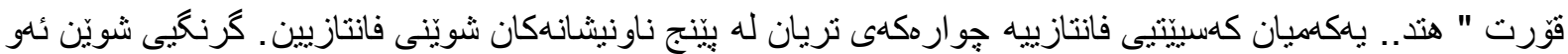

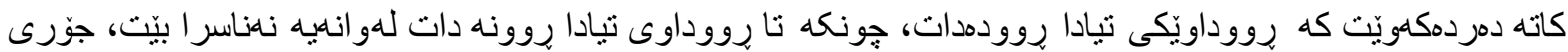

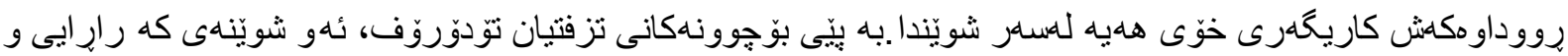
سالرسوريمان دروست دهكات، شوينّى فانتازييه.

\section{تهوهرهى دووهدم: جوّرهانى شوخنى فانتازى لله رؤماندا:}

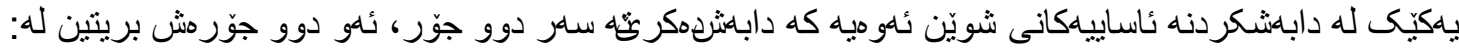

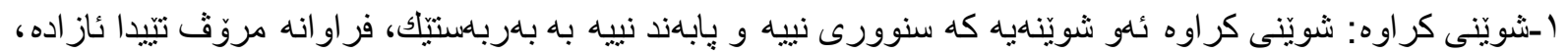

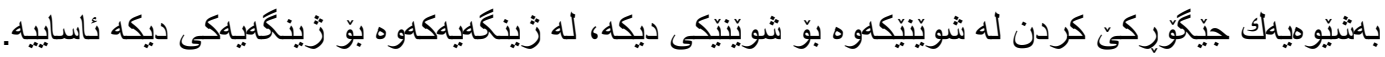

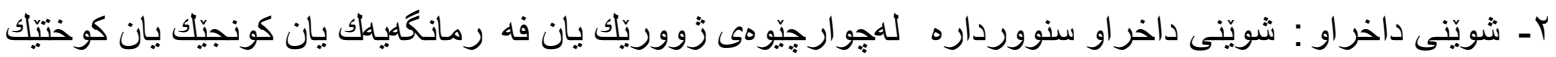
مروّف نتيدا وهكو شويّنى كراوه ئاز اد نييه.

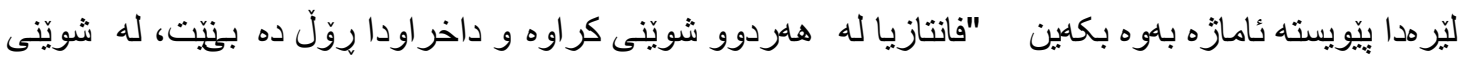

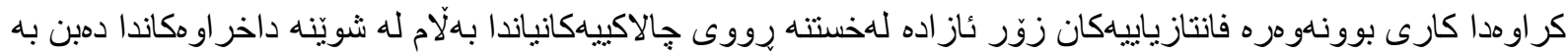

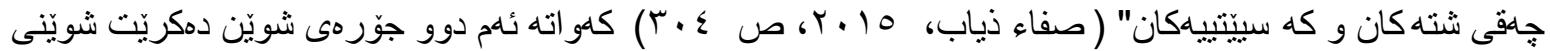

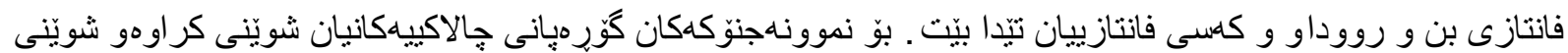

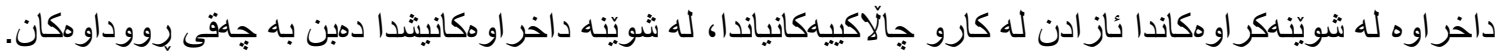

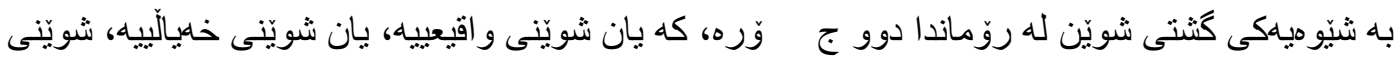
خميالّيش دوو جوَرْو بريتين له:

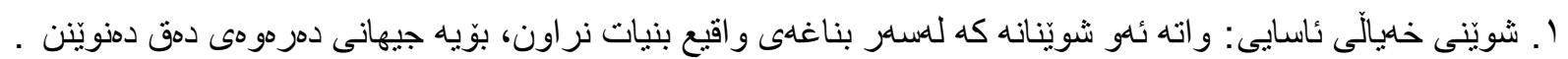

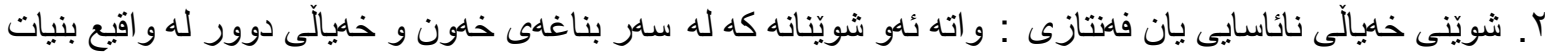

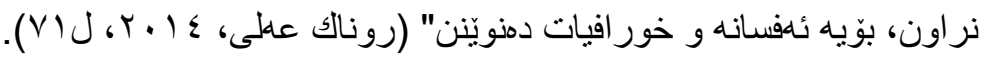

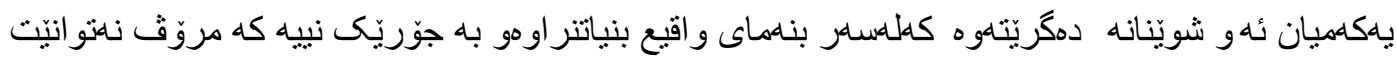

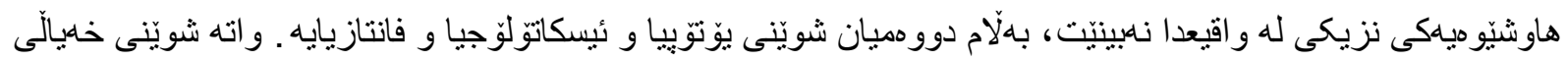

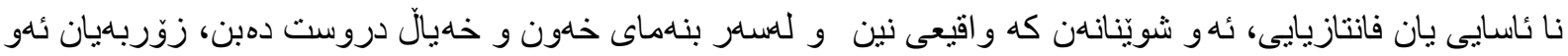

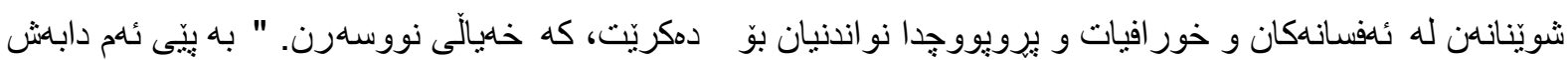

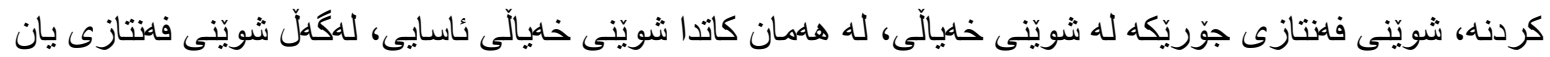

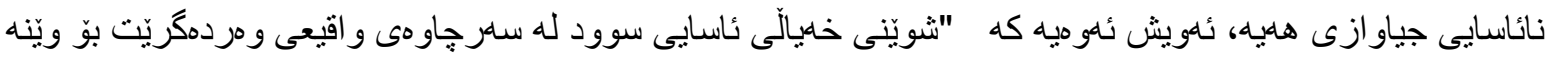




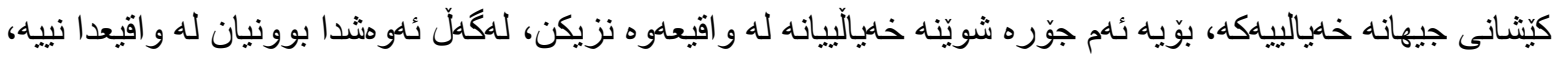

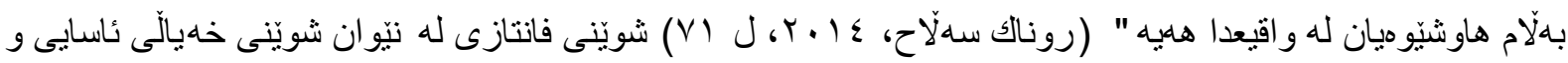

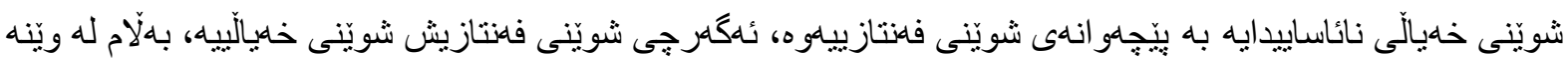

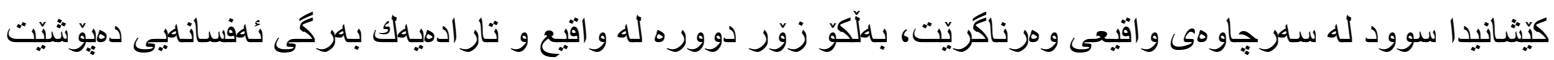

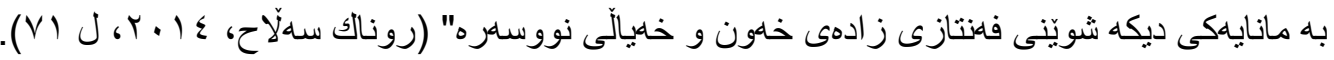

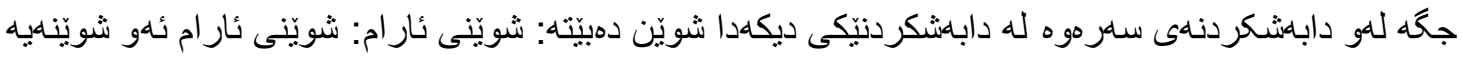

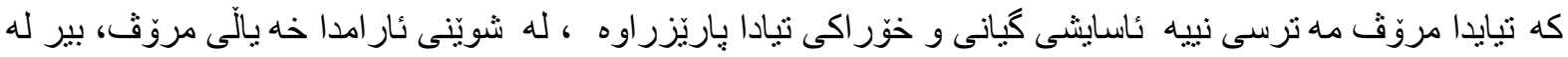

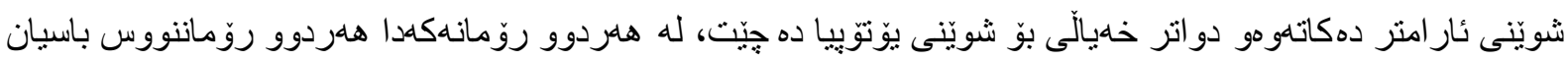

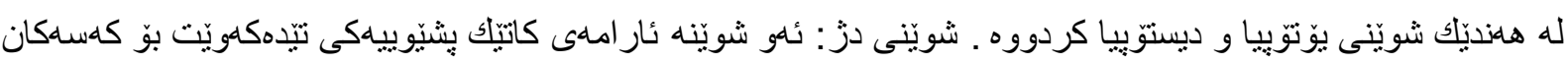

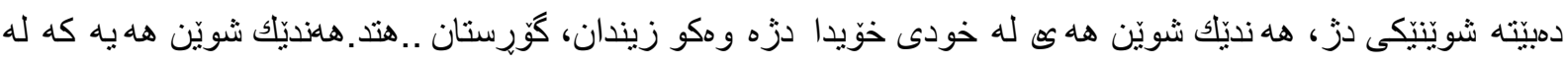

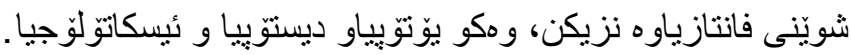

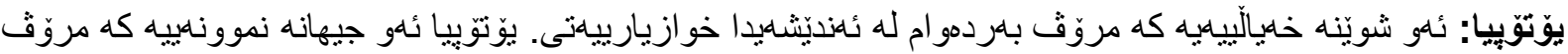

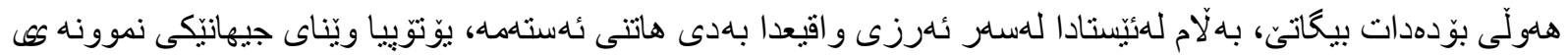

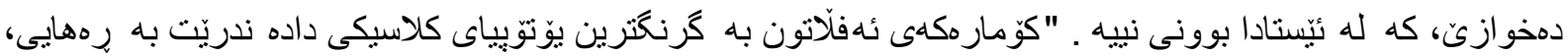

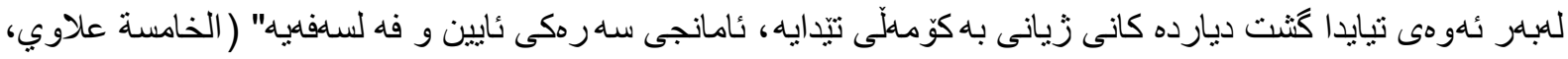

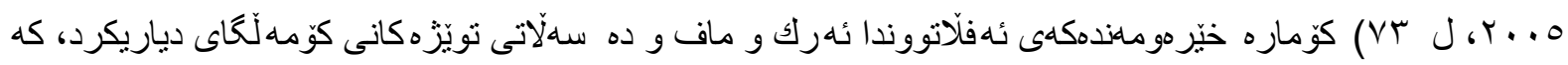

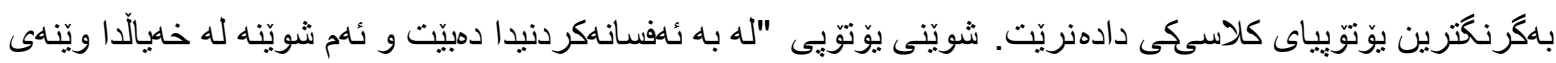

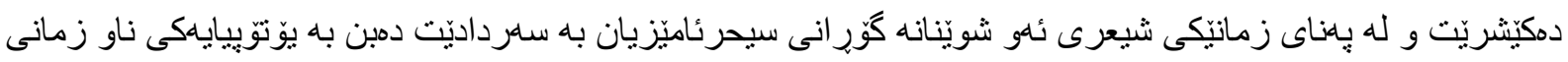

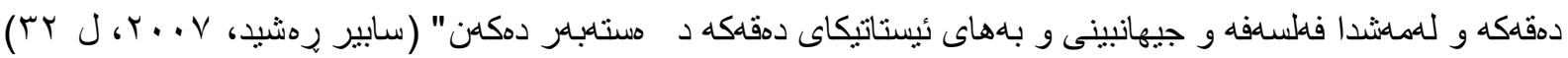

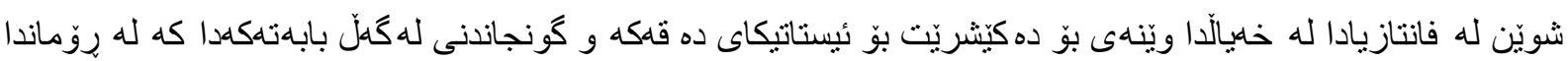

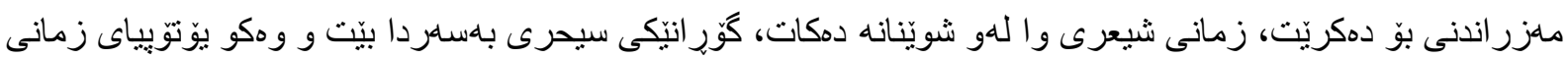

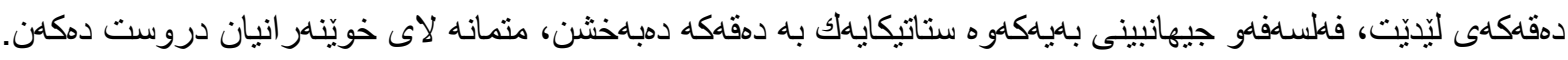

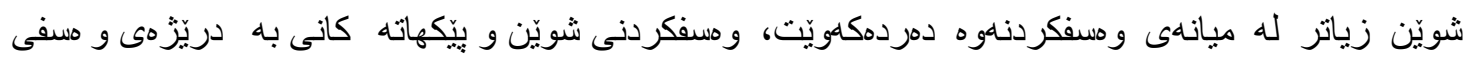

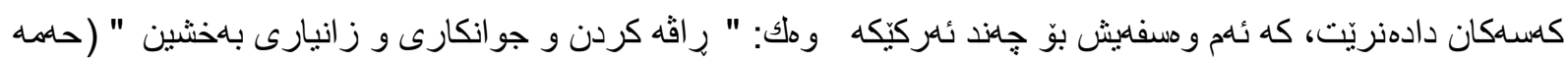

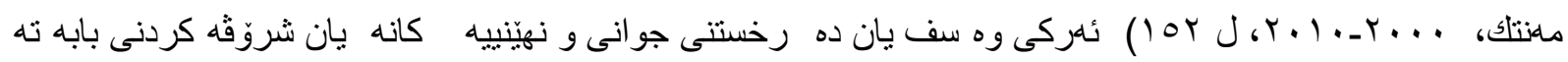

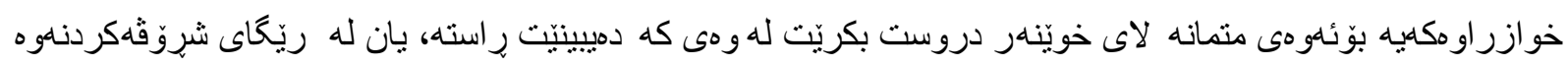

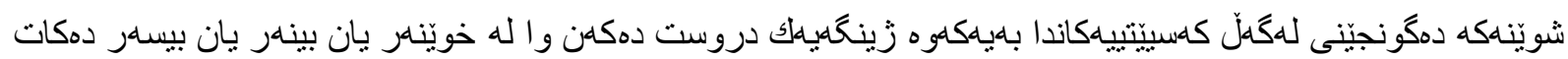

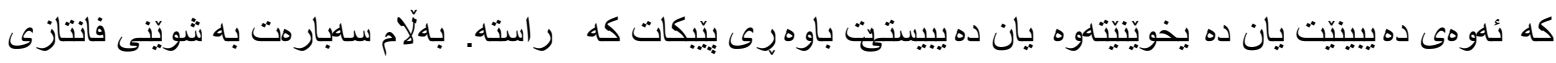

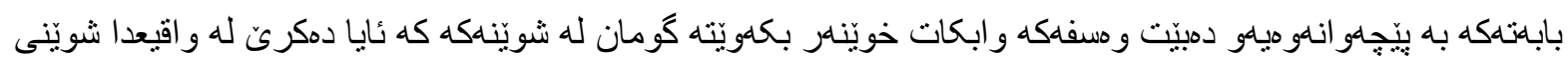
وا هلبيّت.

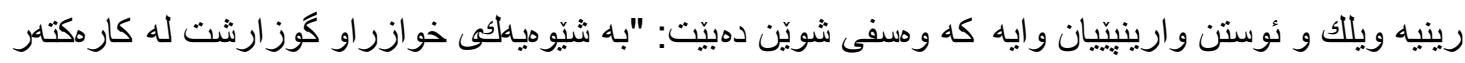

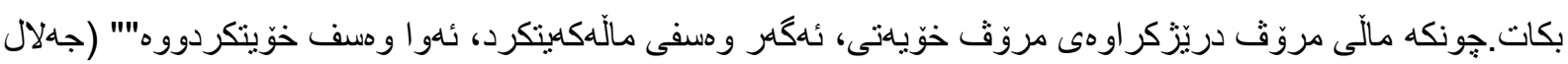

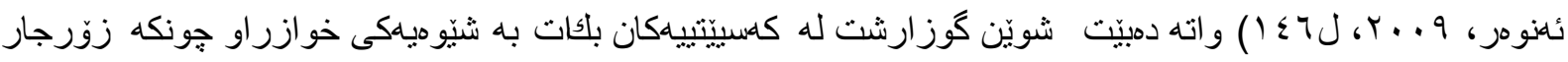

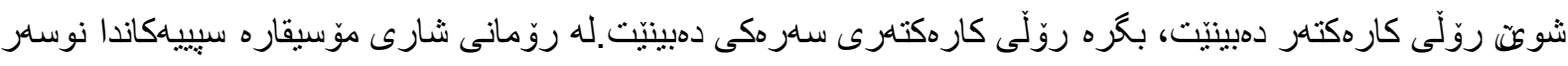




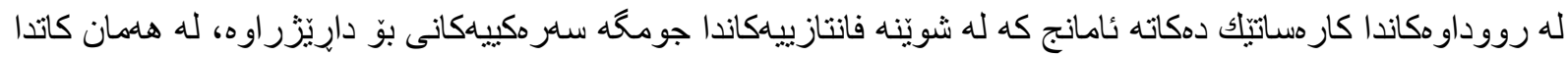

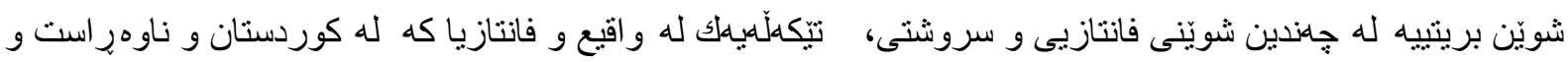

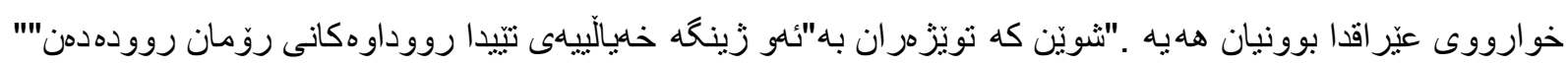

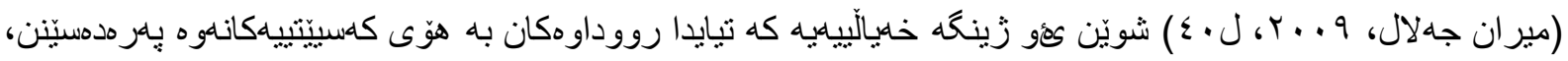

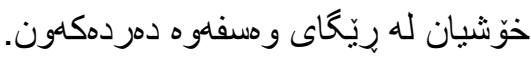

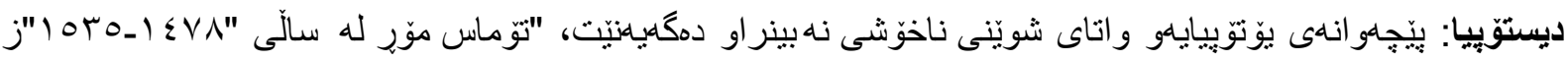

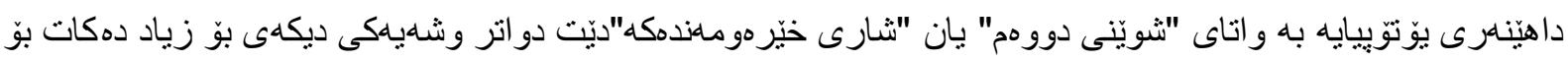

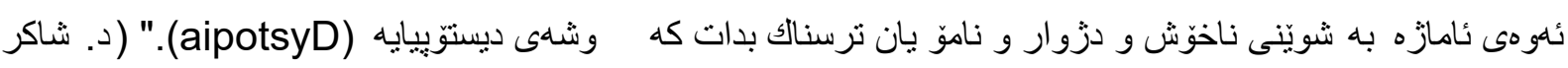

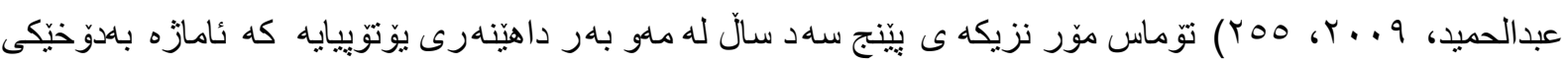

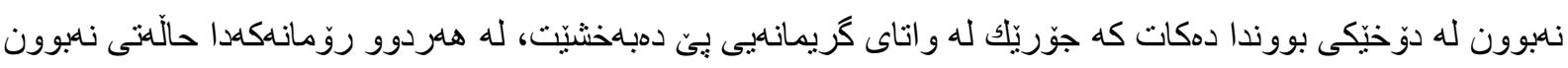

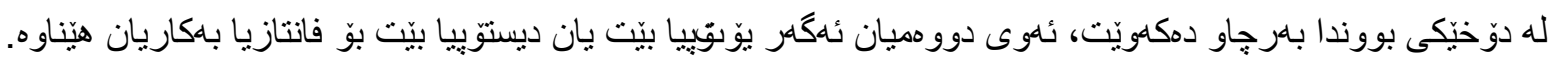

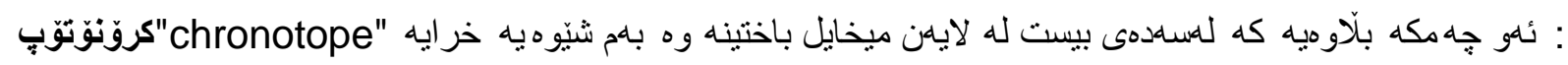

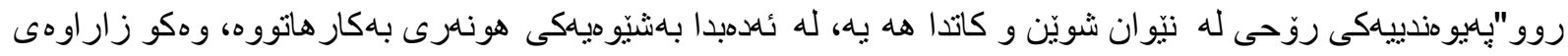

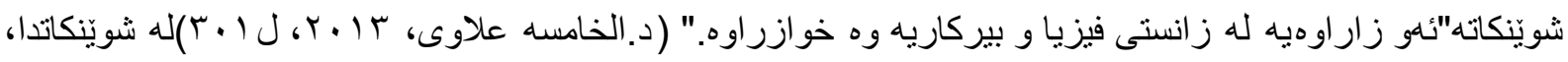

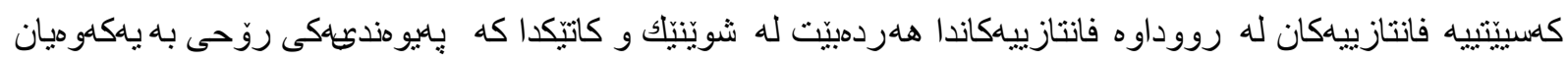

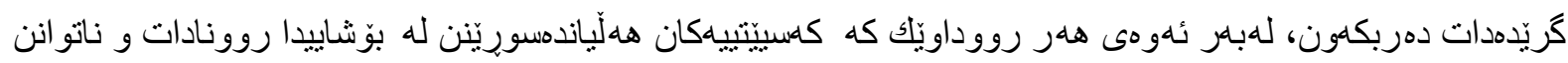

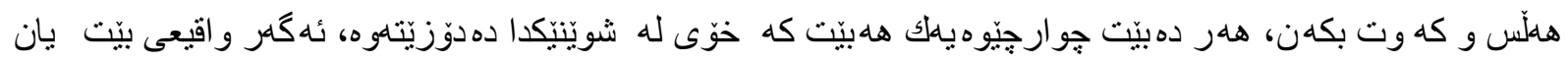

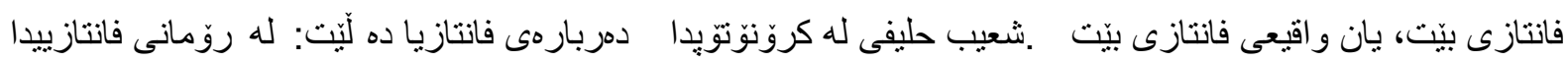

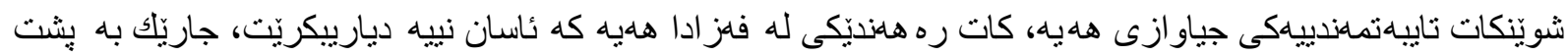
باسنتن به بوّجونهكانى باختينهوه، جاريّكى ديكه به دهقه فانتازيهكان كه تيايدا كات دريّز ده بيّت و كورتده بيّناهوه به بيّيى

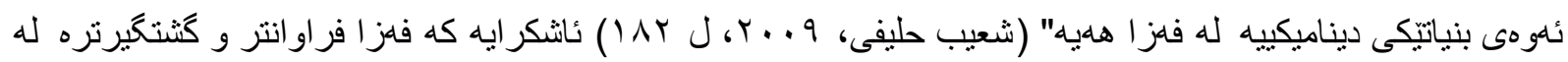

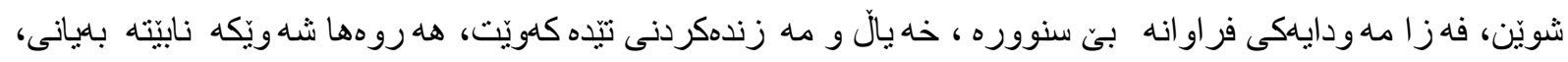

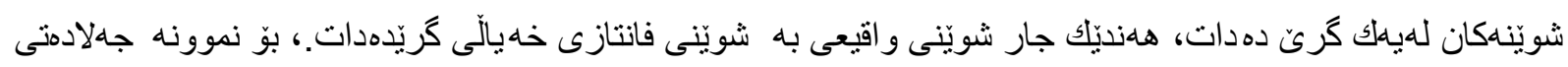

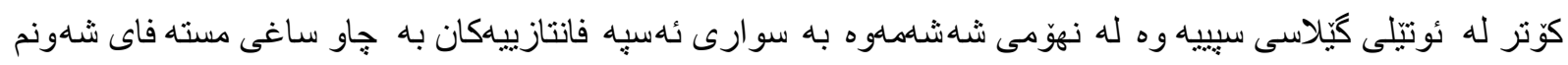

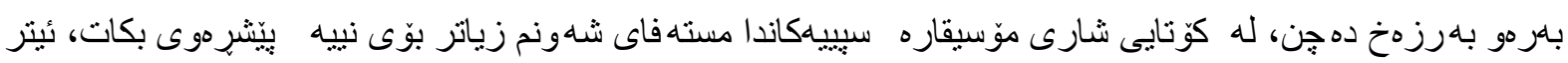

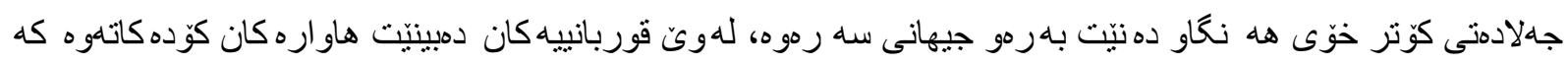

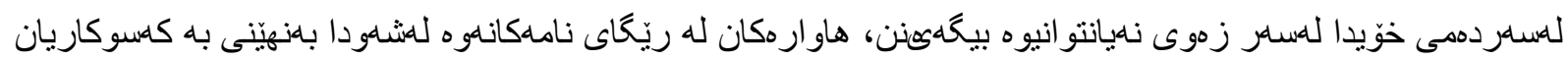

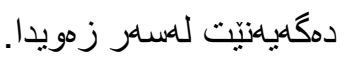

شويَّه فانتازييهكان، و ابهستاعى شوينّيكى فانتازيى دياريكر او نين، يان مه رج نييه رووداوى فانتازى تهنها للهو

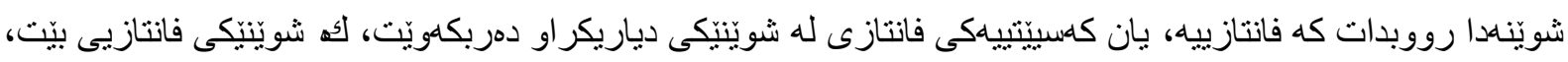

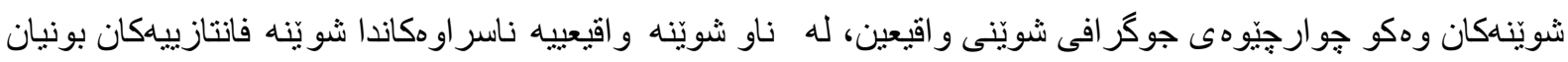

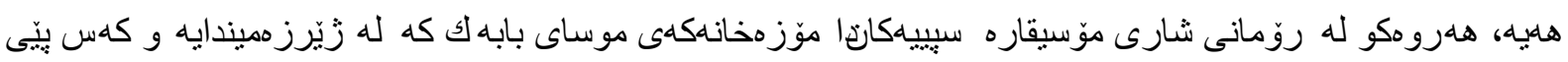

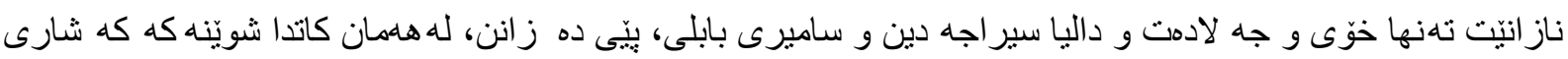

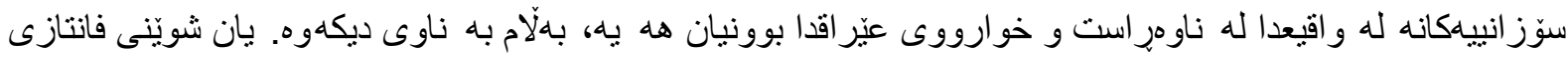




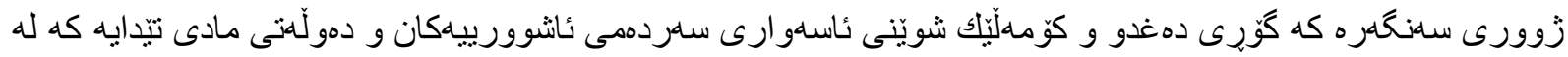

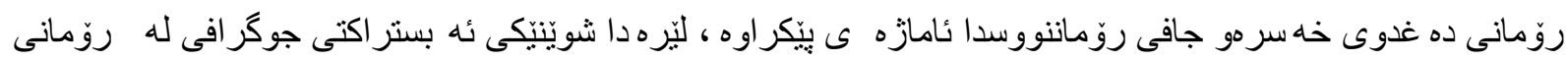

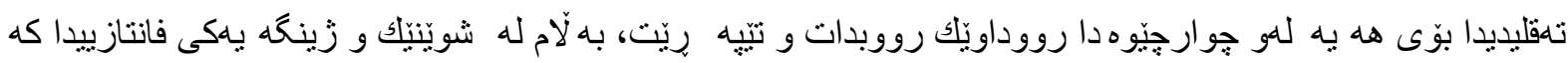

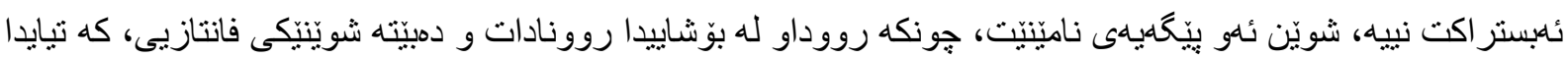

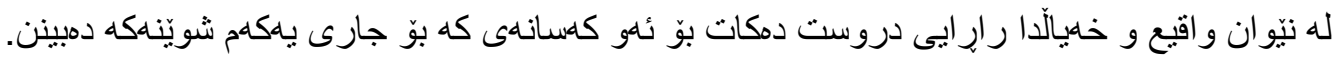

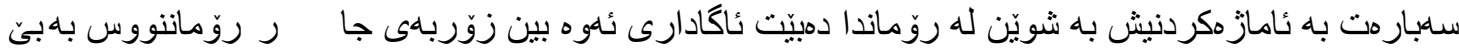

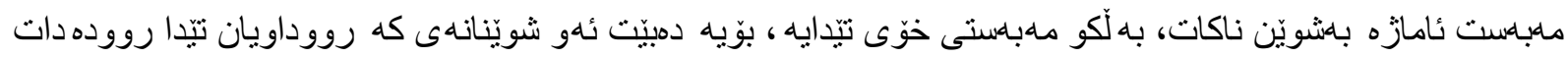

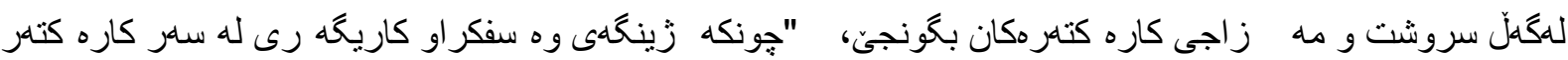

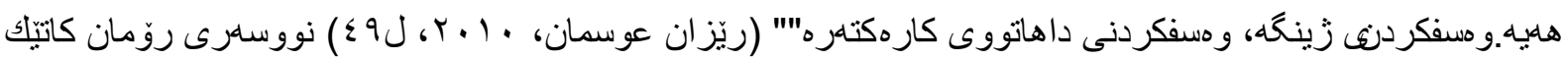

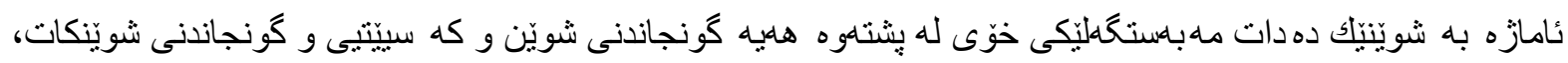

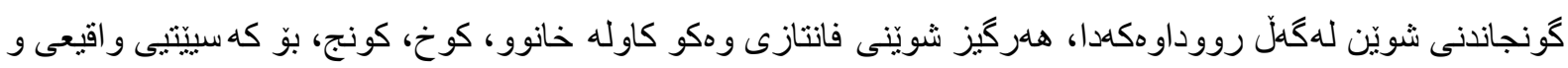

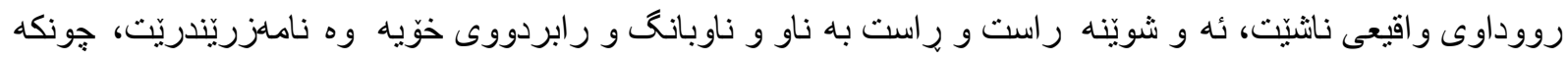

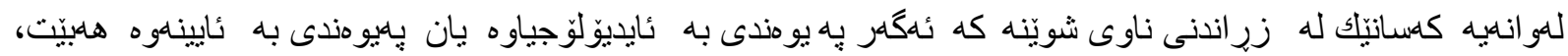

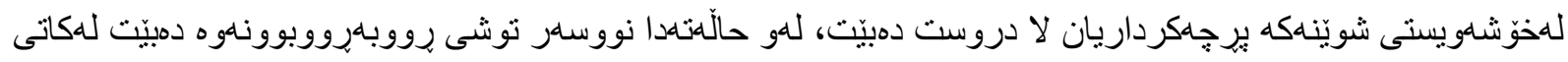
زير اندنى ناوى شويَنيكدا.

فانتازيا له هاموو حالّنتيكدا خهيالّى نووسار نييه، هلنديّكجار مروّث به عهفهوى تووشى شوينى فانتازى دهبيّت

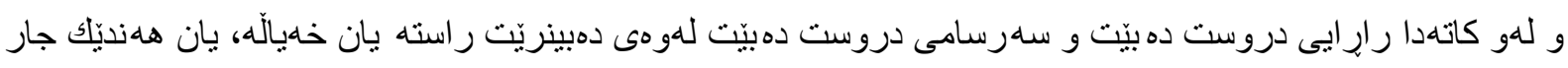

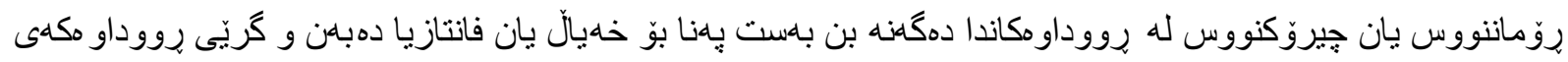

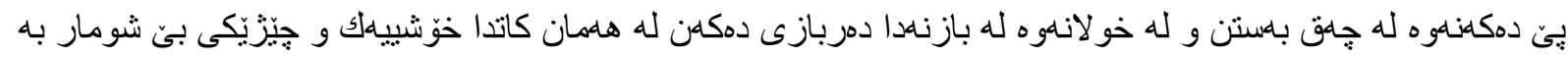

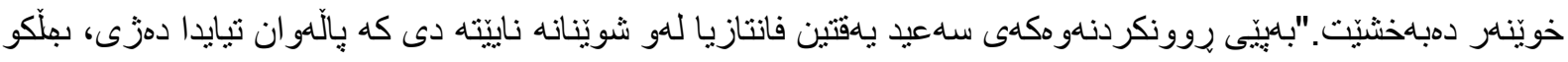

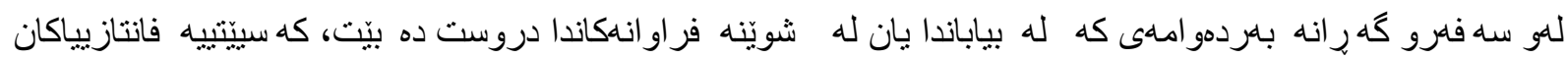

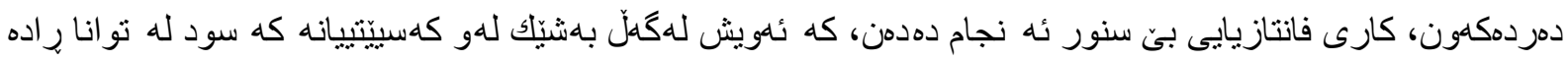

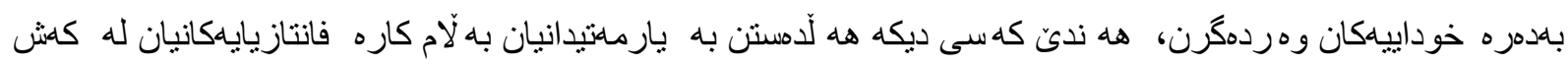

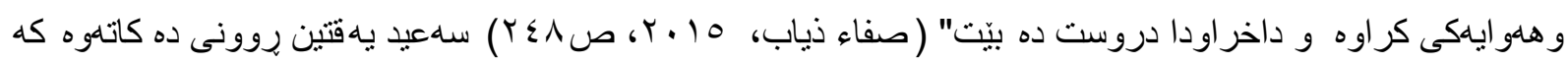

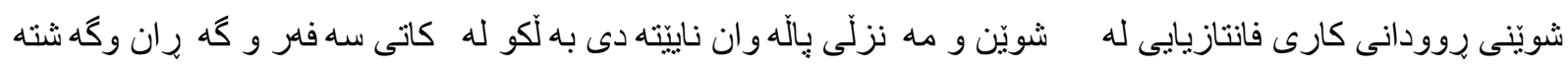

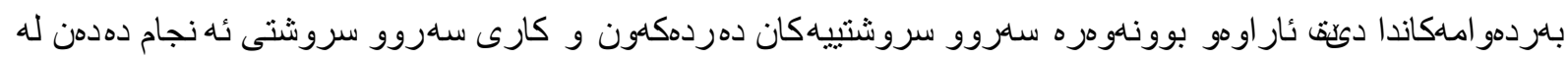
كشش و هلو اى كر اوهو داخر اودا.

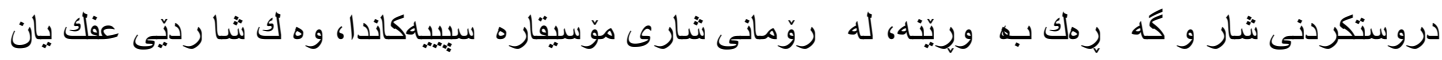

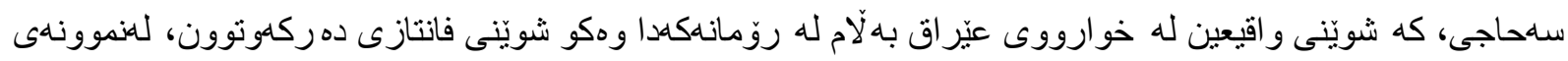

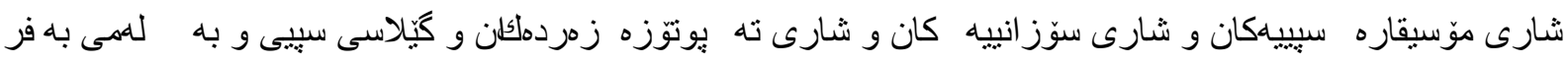

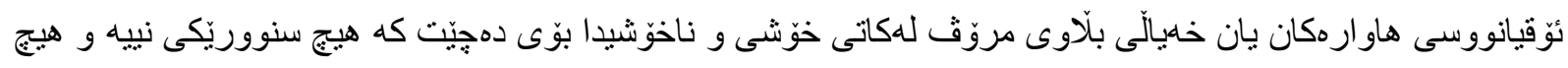

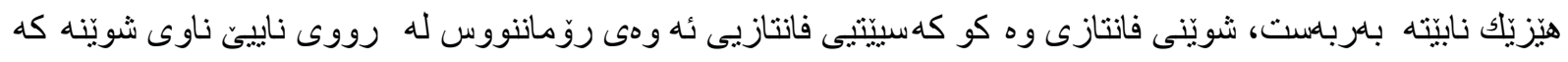

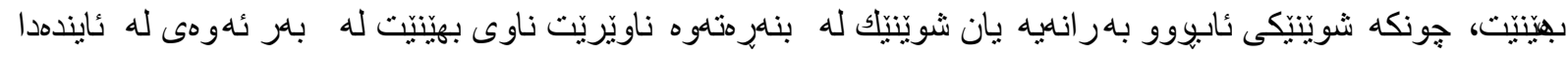

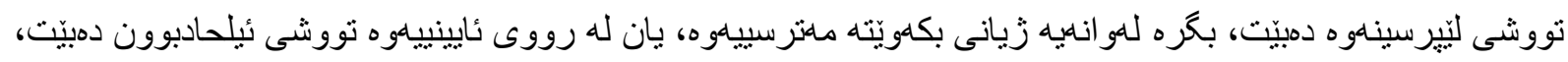




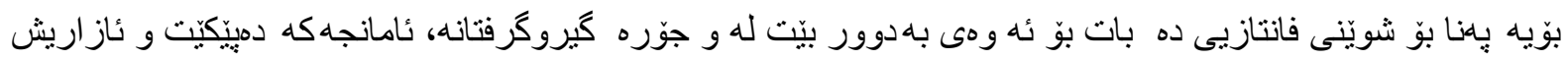
نادريّيت .

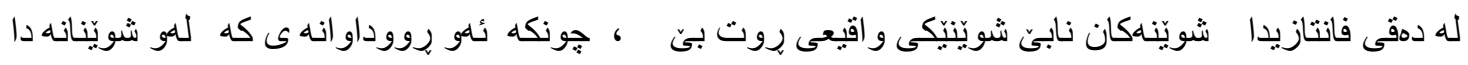

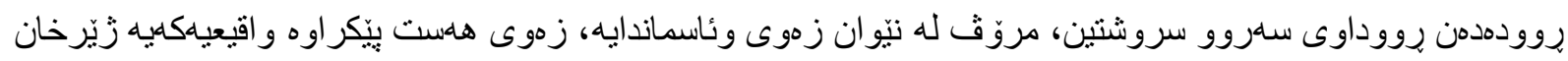

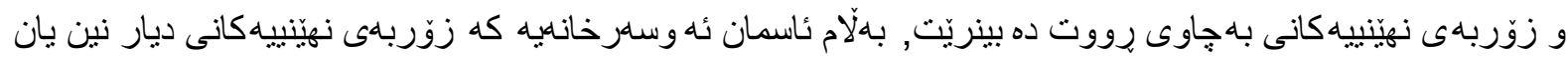

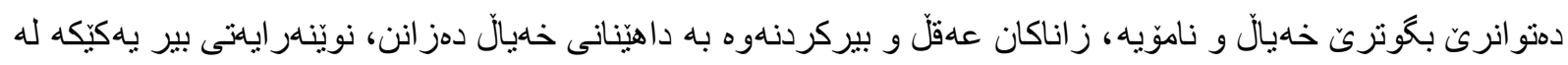

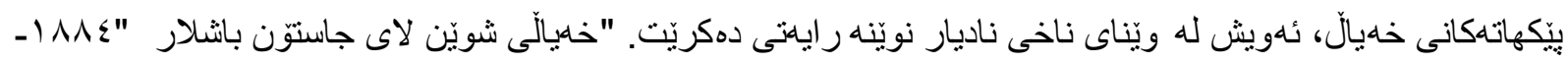

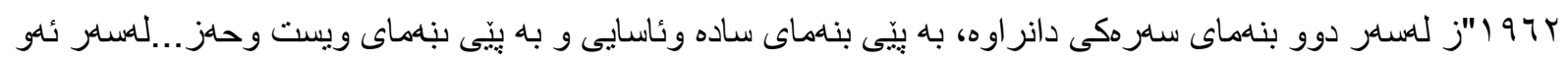

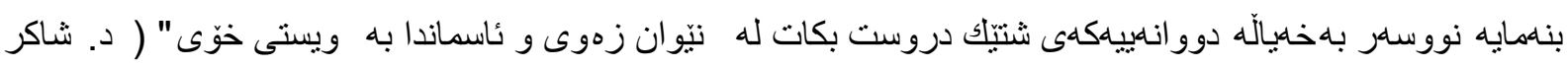

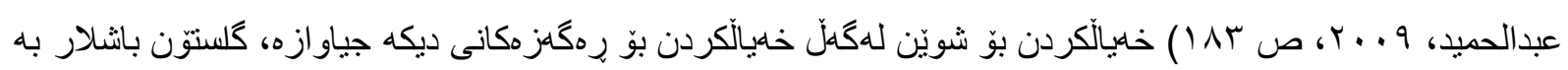

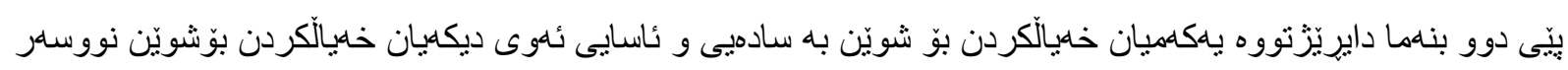

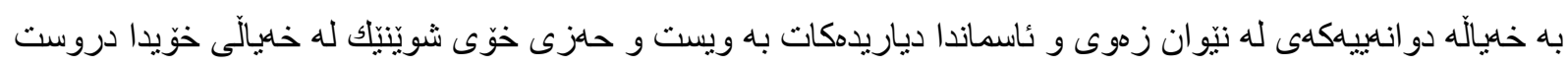

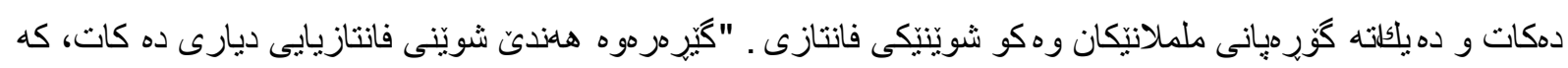

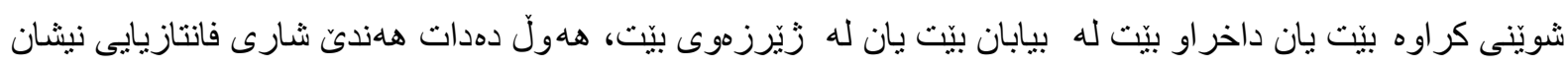

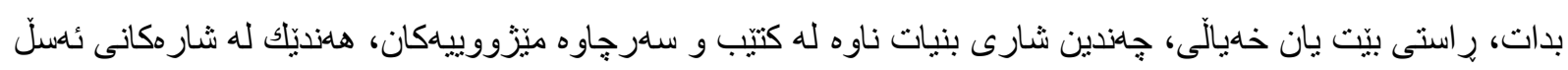

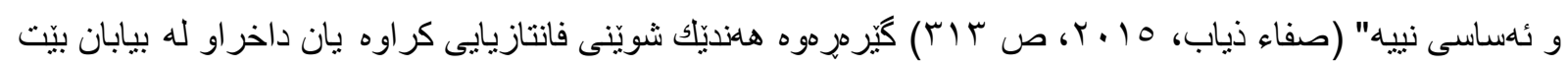

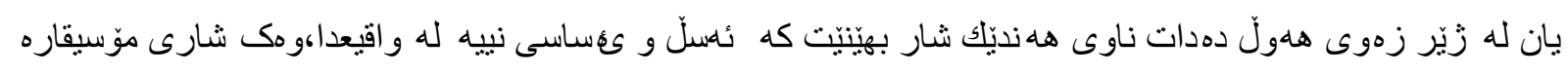

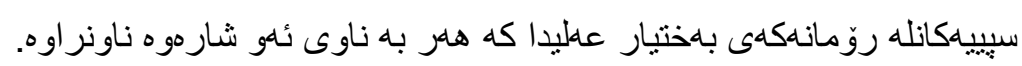

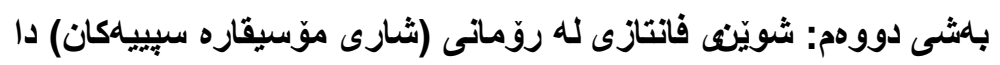

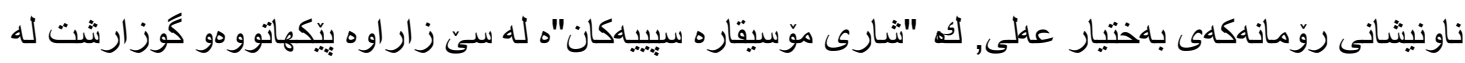

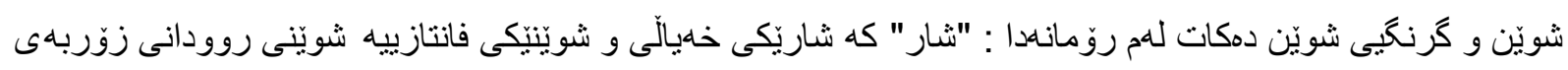

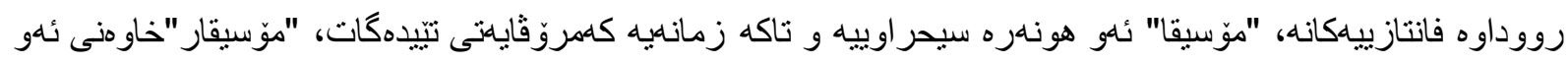

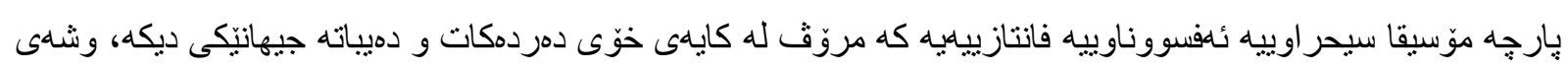

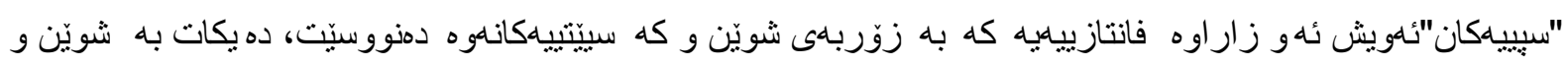

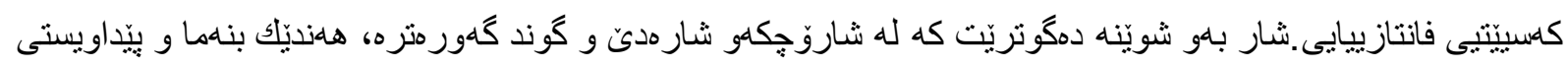

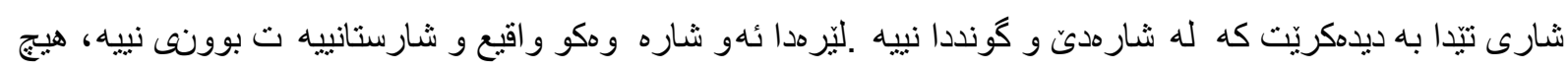

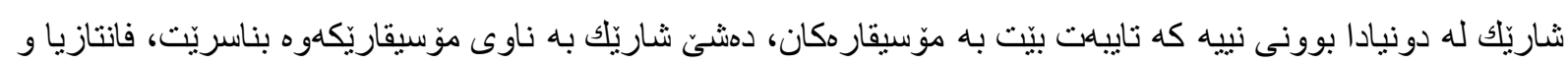

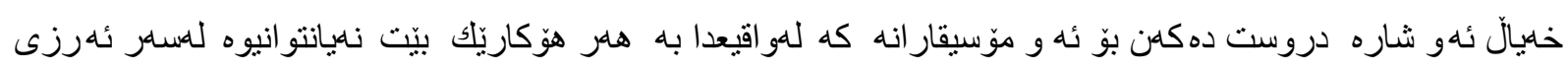

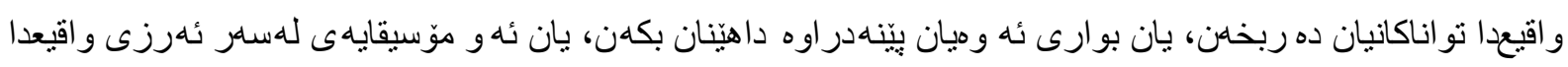

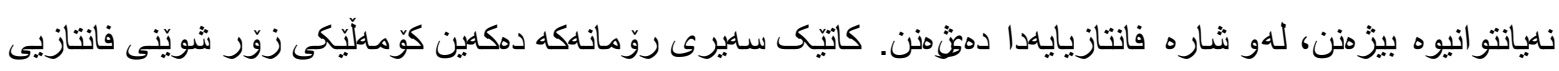

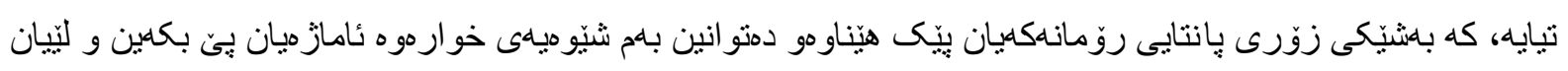
بدويّين:

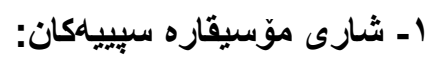


ناونيشانى روّمانوكهى بهختيار علييه و شاريّكى فانتازيى و خه يالّيبه، هلروهها ناو نيشانى تابلوّيه كه، له ناو

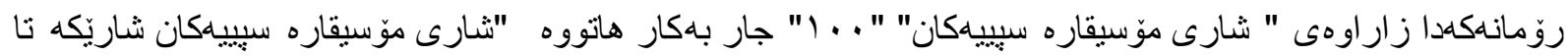

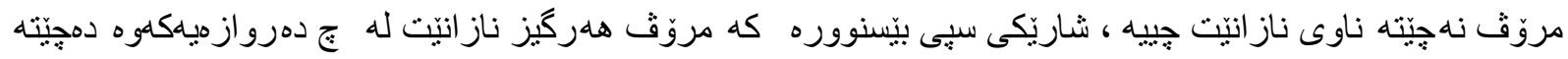

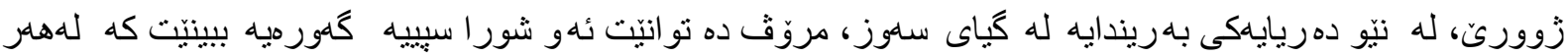

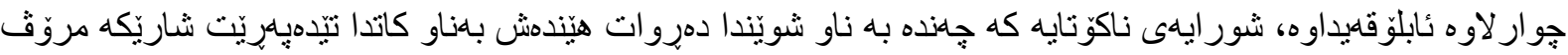

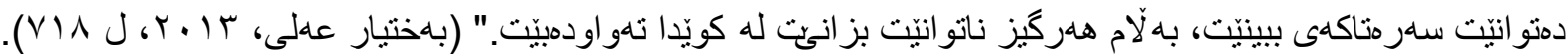

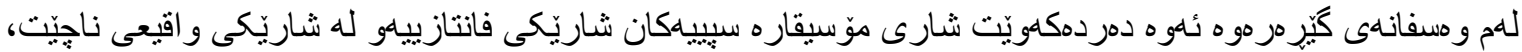

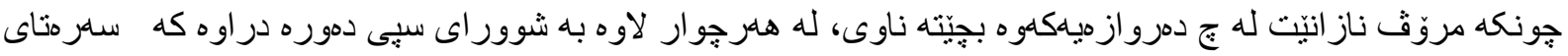

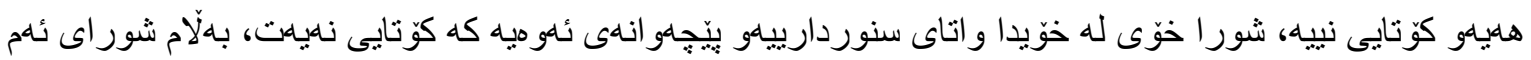

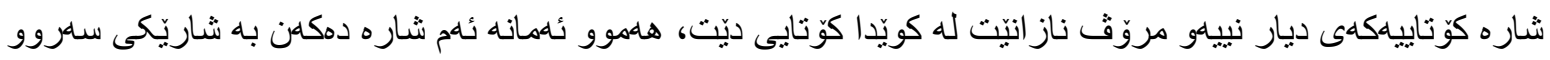

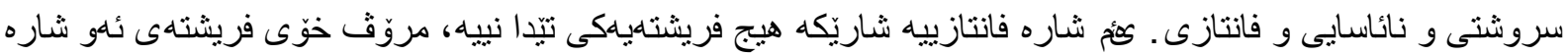

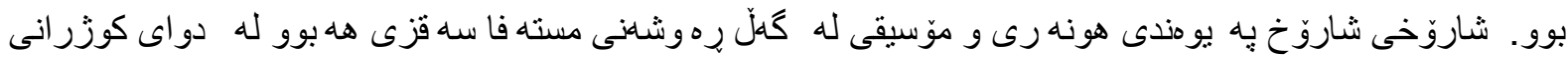

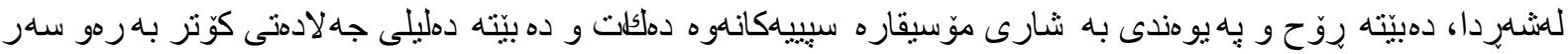

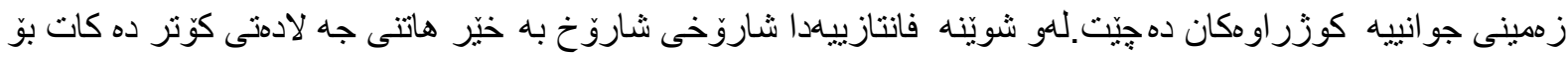

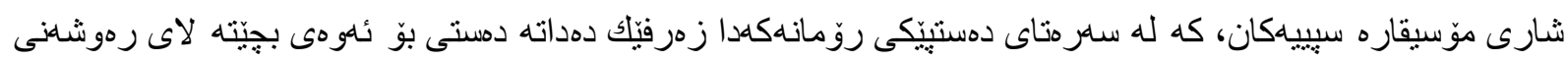

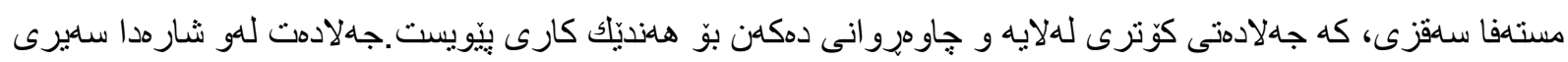

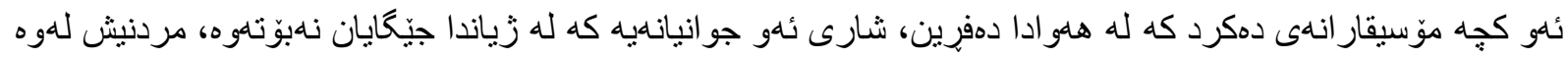

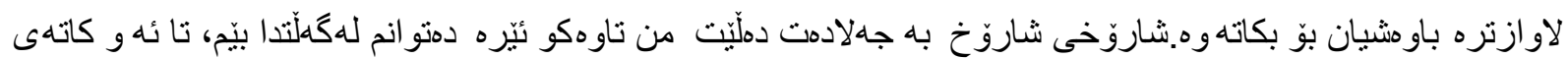

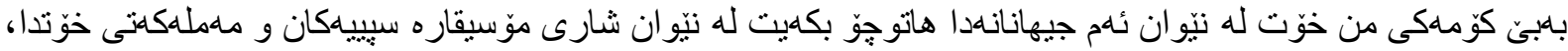

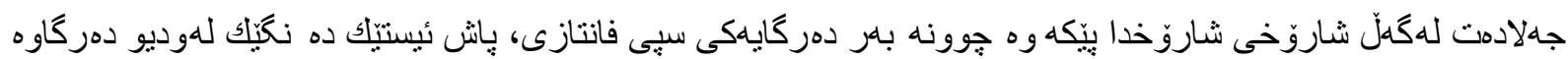

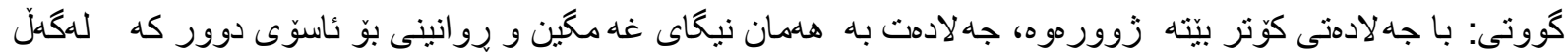

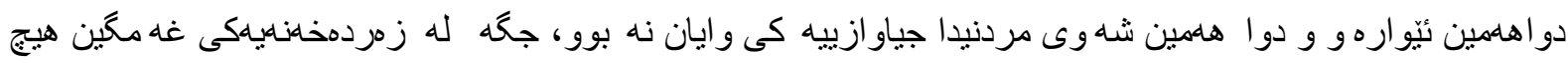

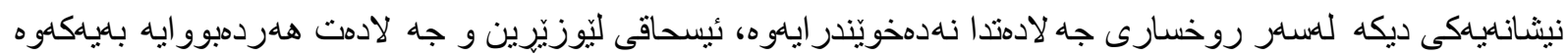

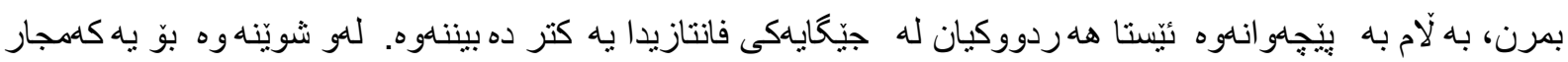

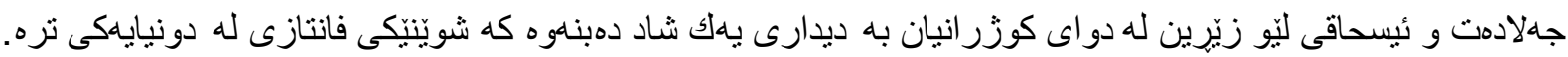

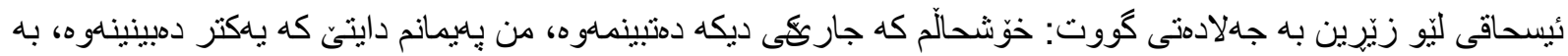

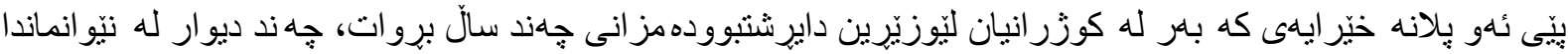

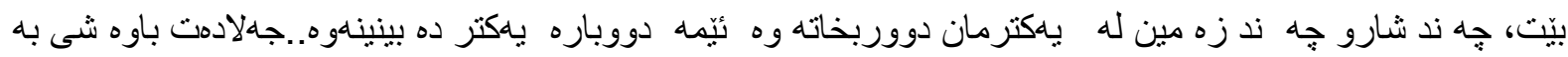

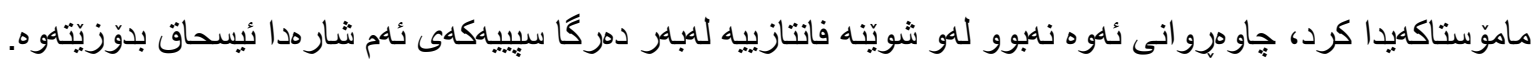

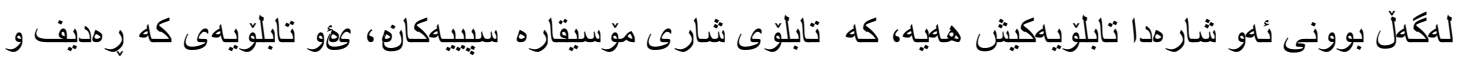

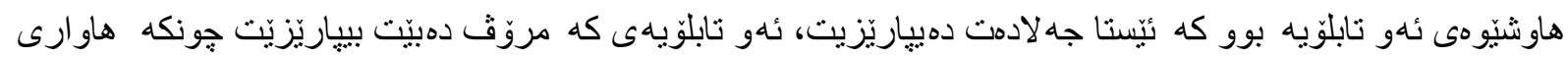

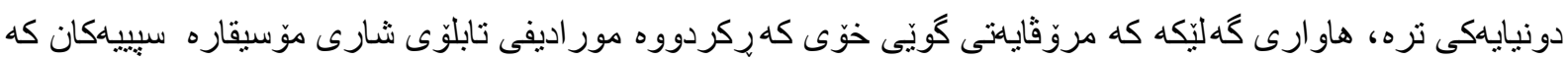
لاى موساى بابهك و جهلادهت و مستهفا شاهونم هلبوو، ئدو تابلوّيه دهيّت بياريّزريّت، واتاكهى هاوارى دونيايهكى تره

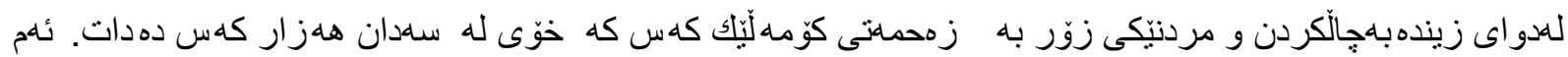




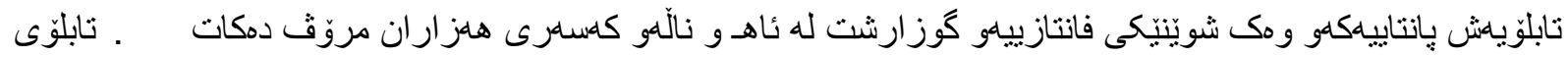

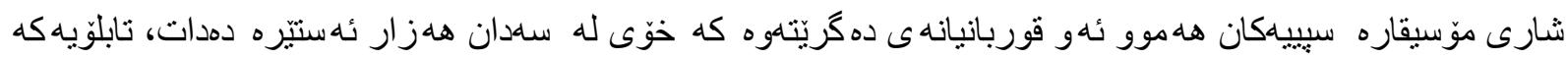

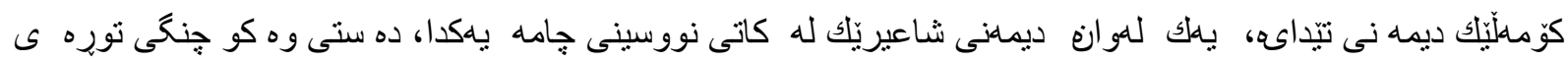

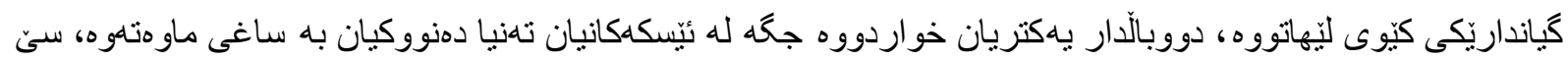

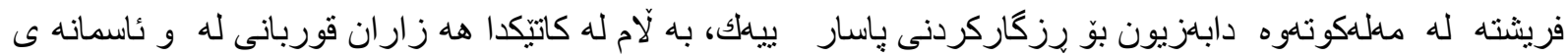

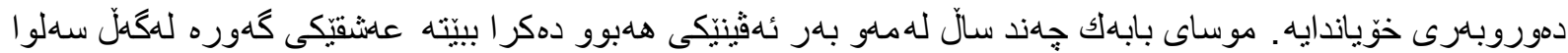

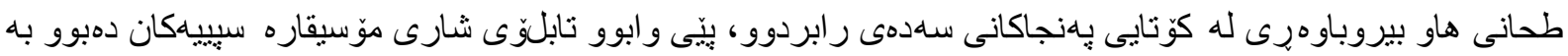

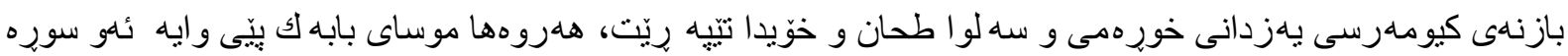

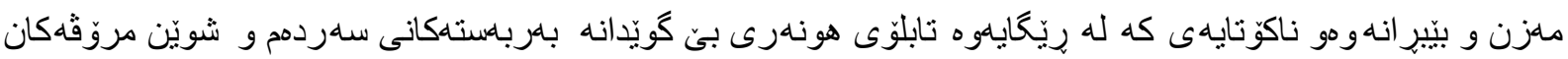

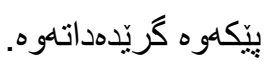

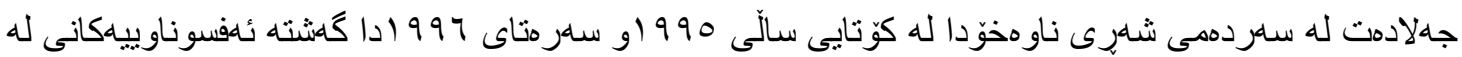

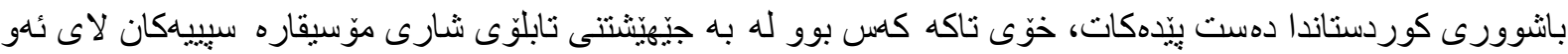

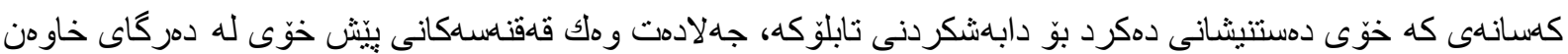

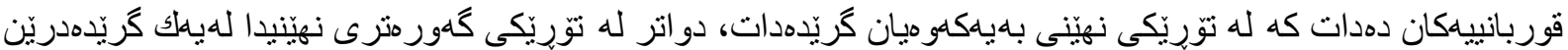

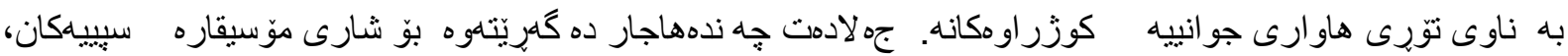

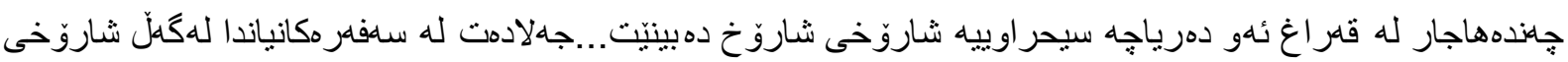

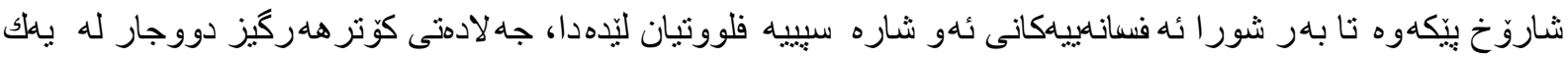

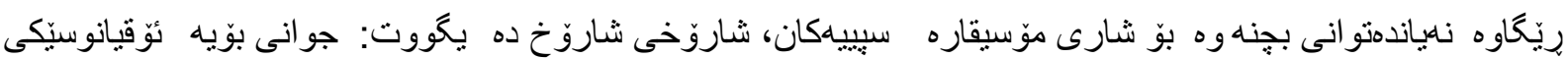

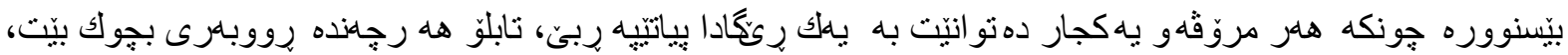

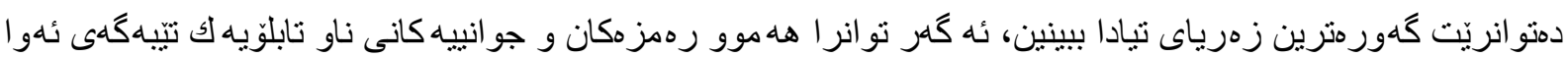

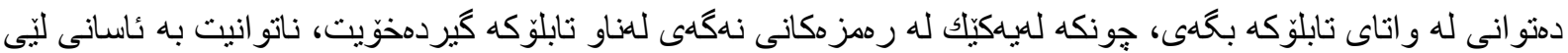

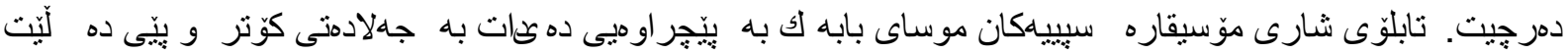

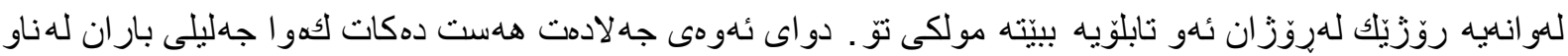

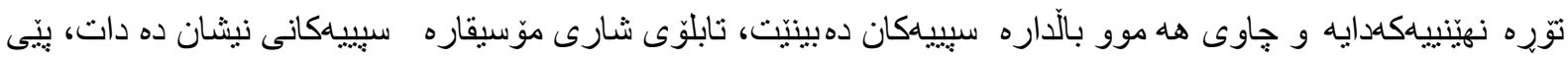

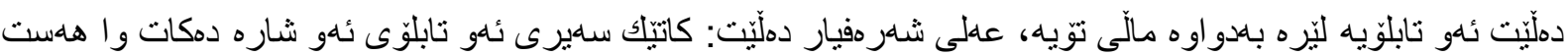

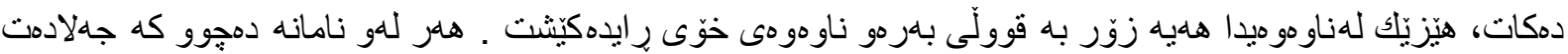
له شارى موّسيقاره سبييهكانهوه دميهيناو دهيدا به كس و كارى قوربانييهكان.

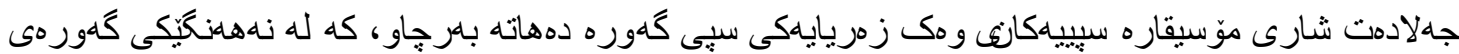

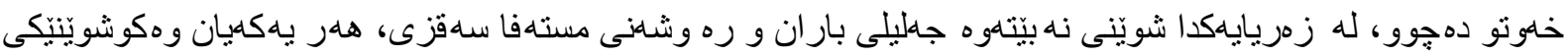

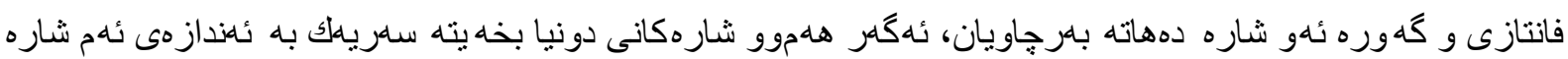

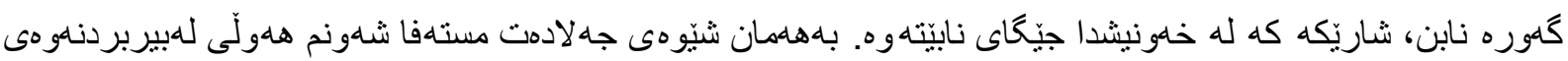

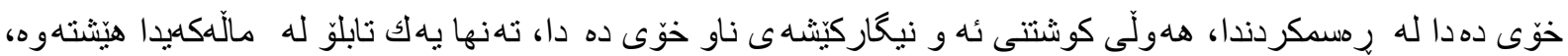

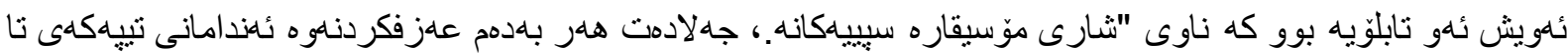

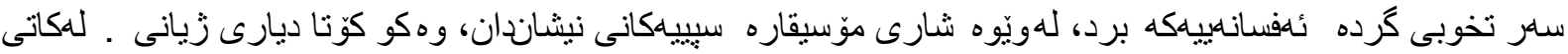




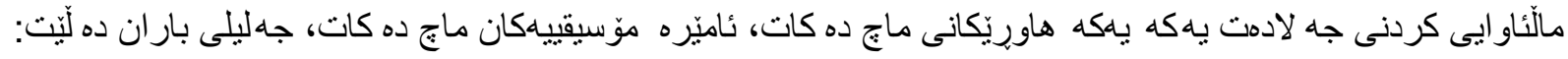

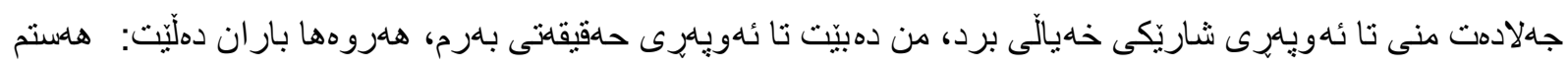

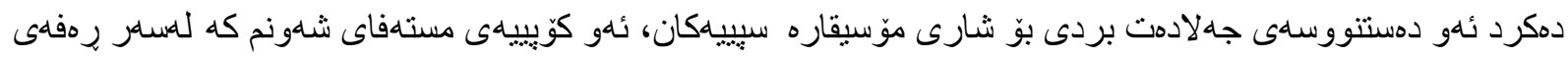

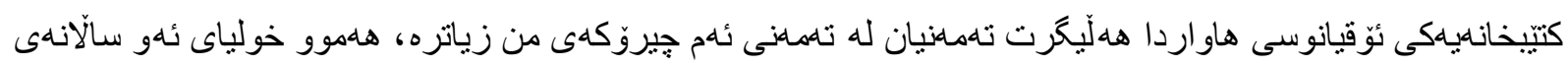

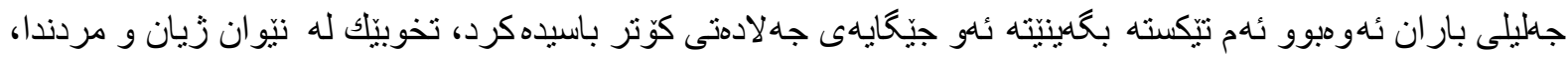

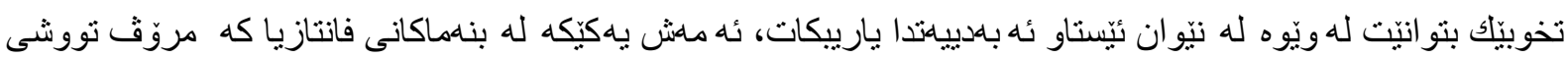

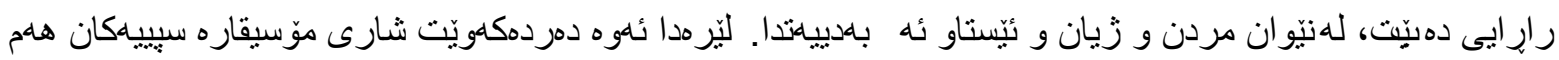

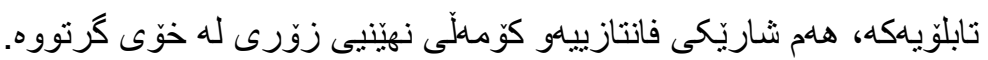

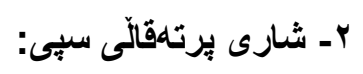

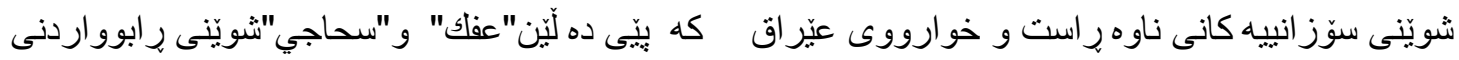

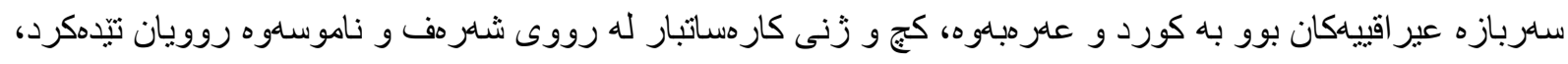

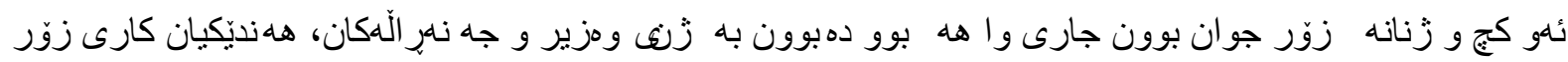

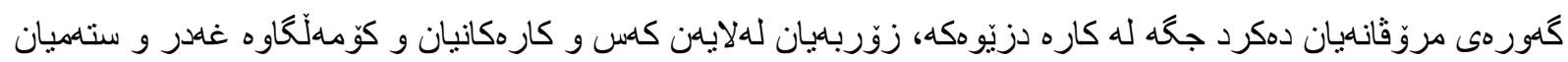

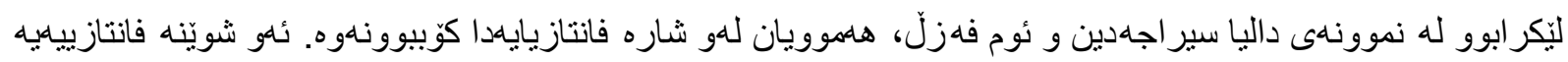

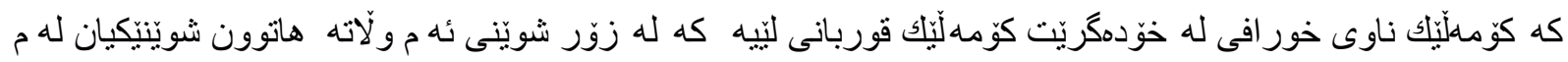

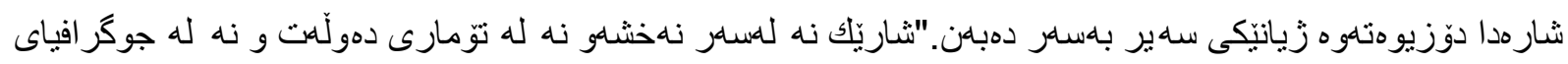

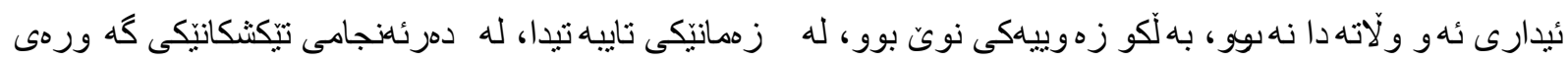

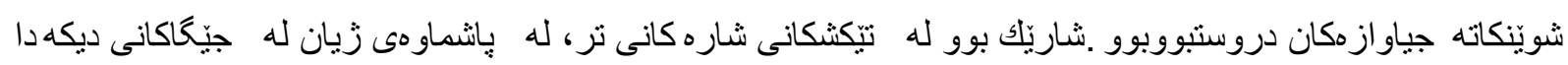

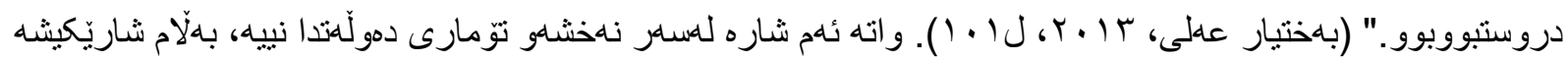

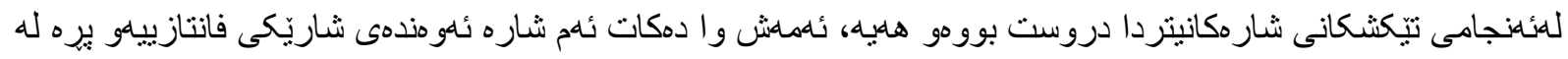

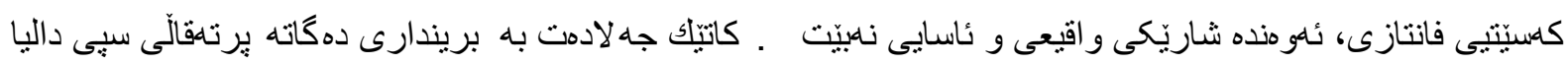

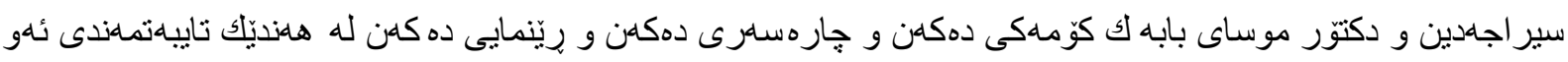

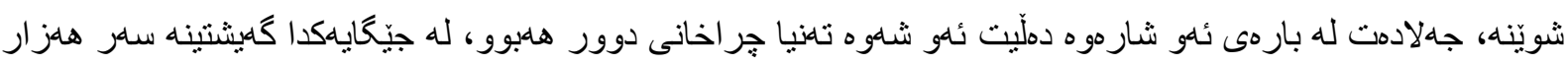

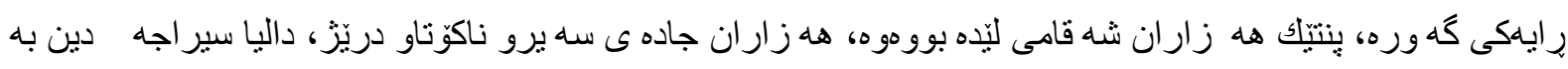

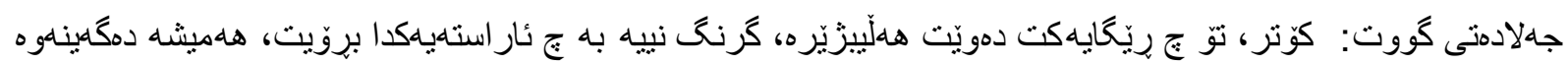

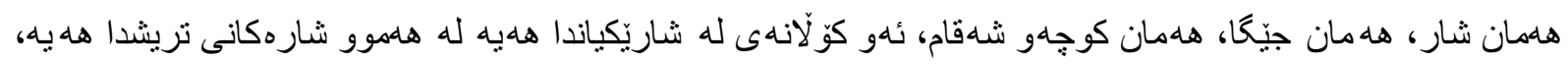

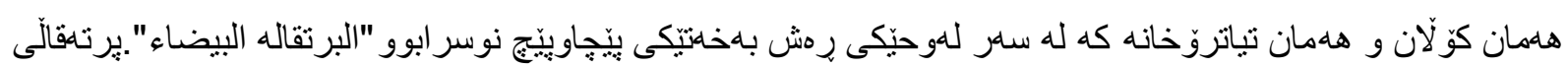

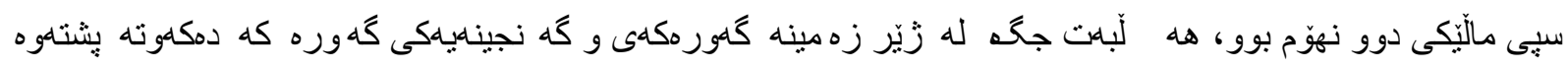

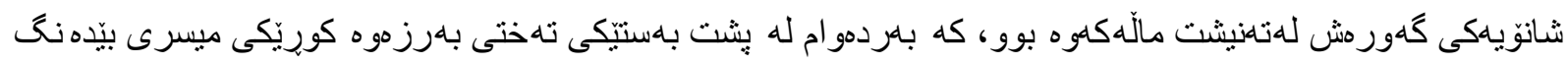

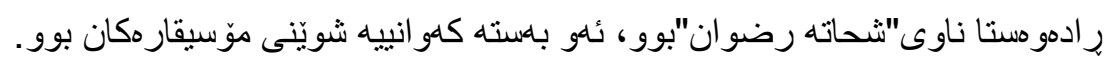

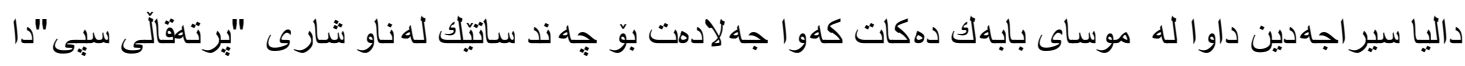

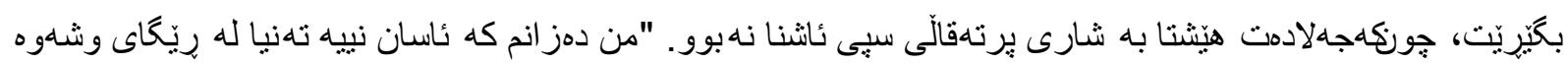

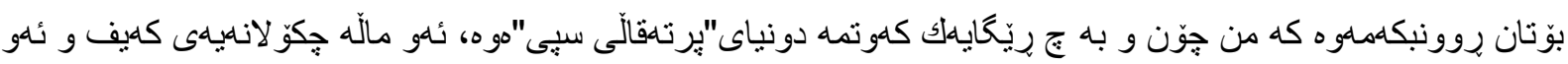

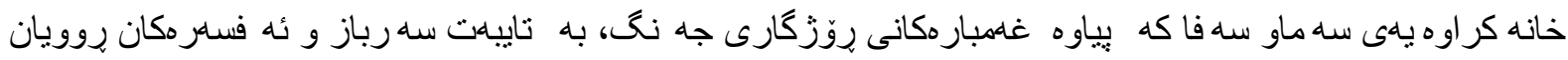




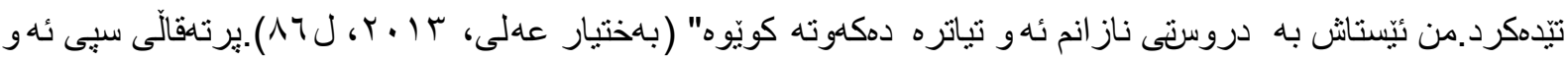

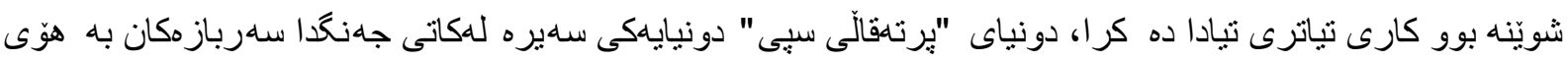

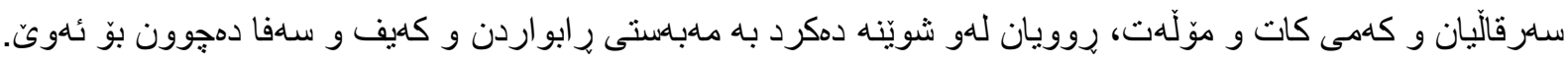

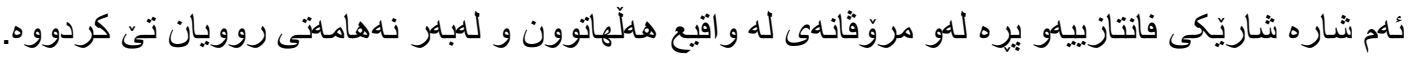

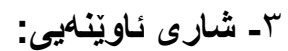

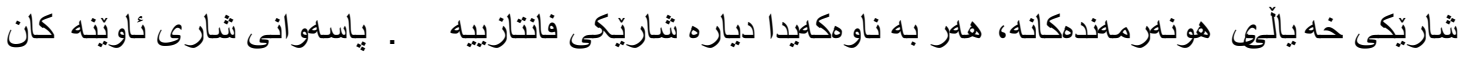

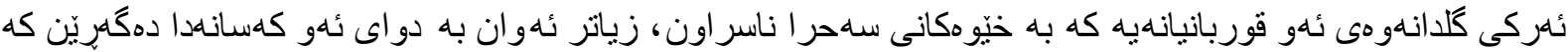

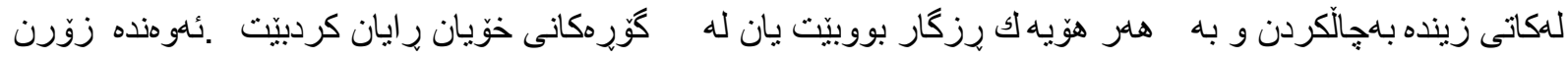

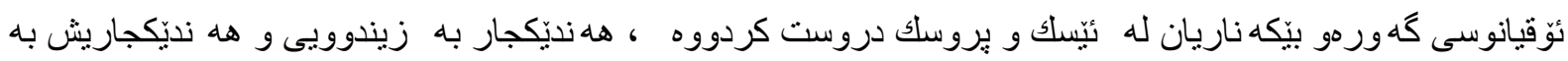

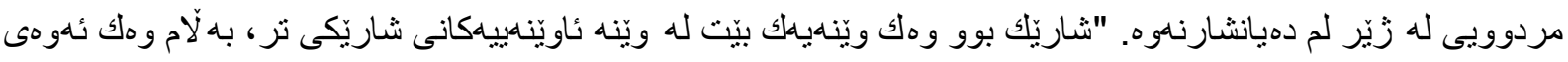

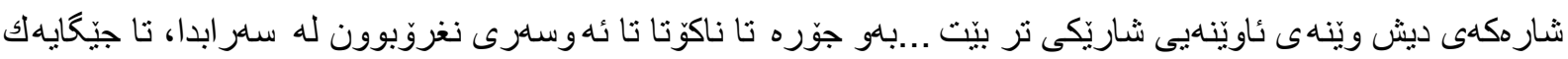

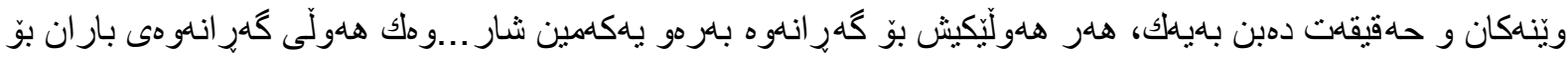

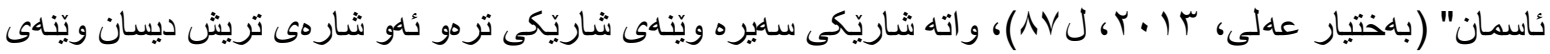

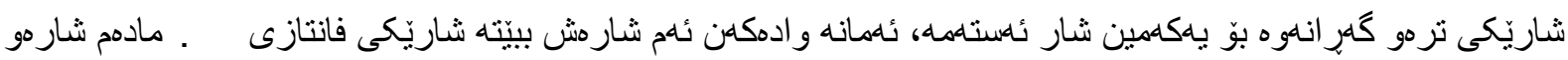

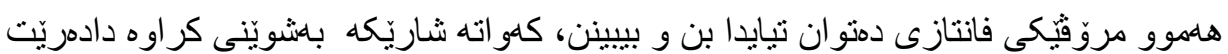

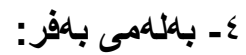

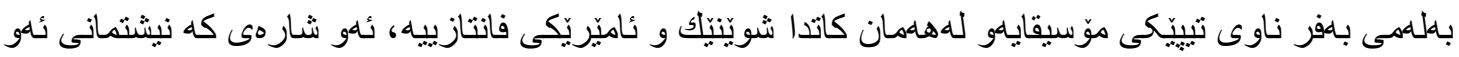

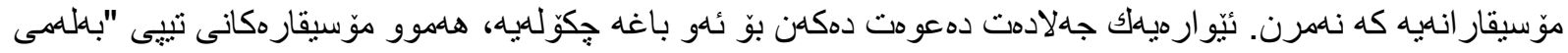

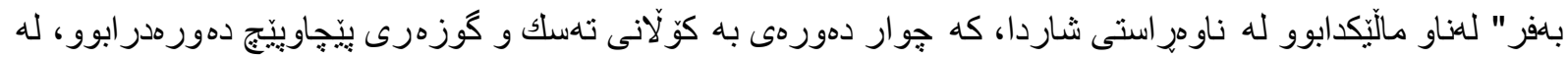

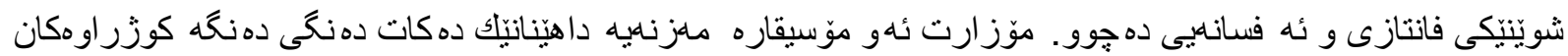

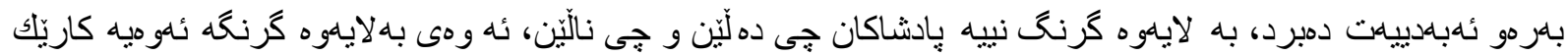

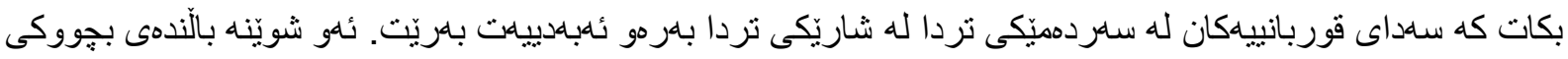

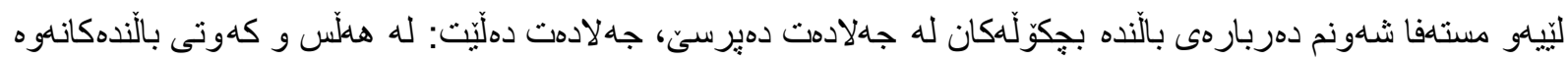

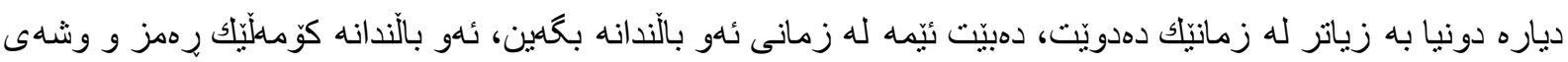

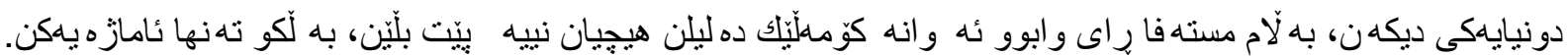

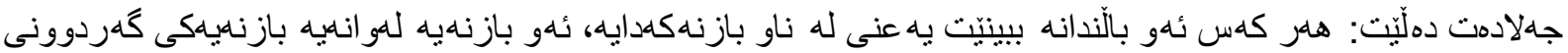

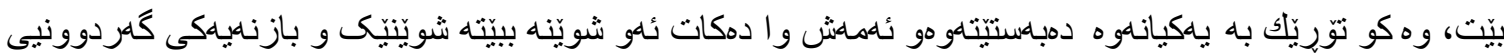
فانتازى.

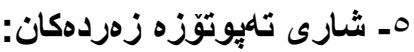

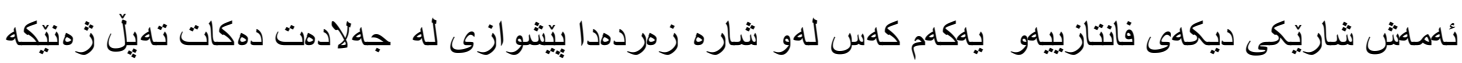

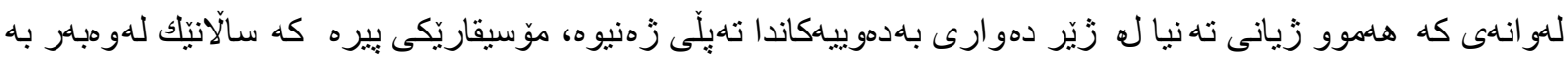

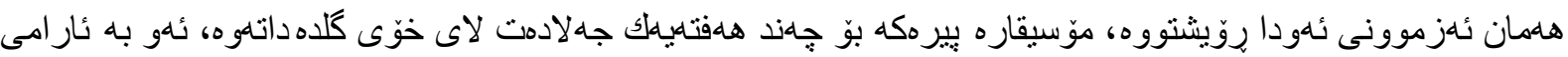

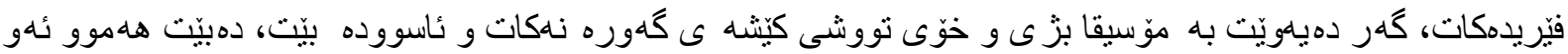

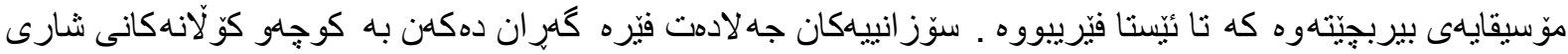




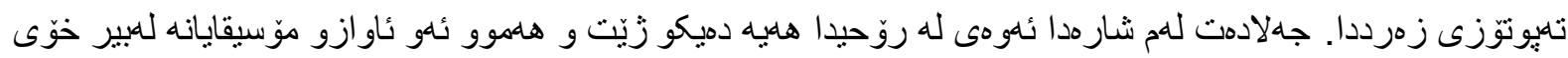

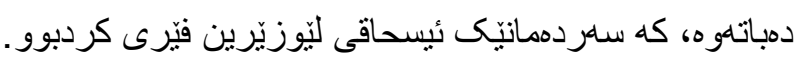

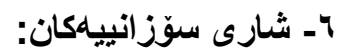

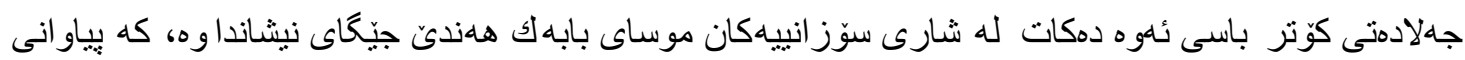

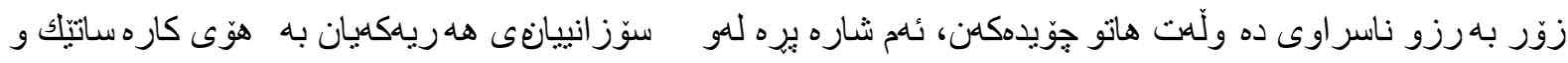

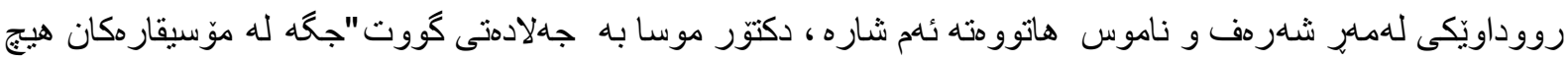

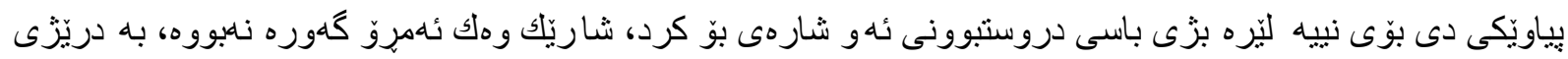

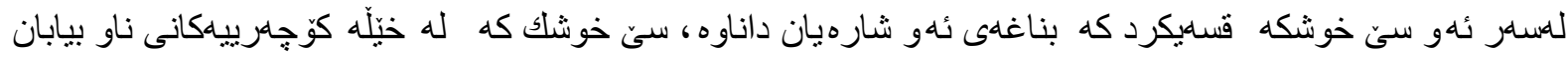

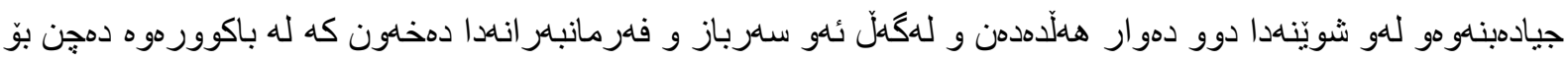

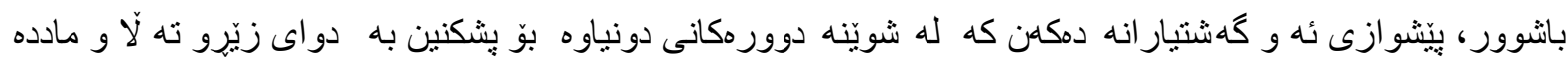

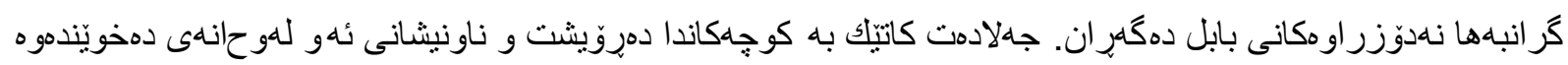

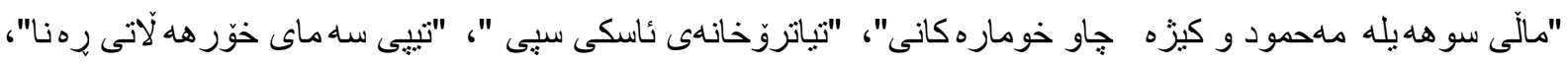

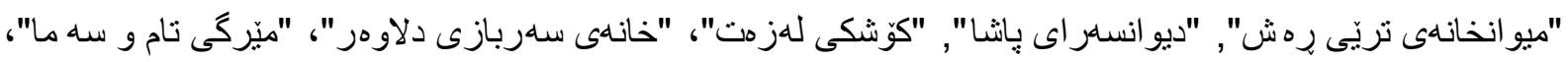

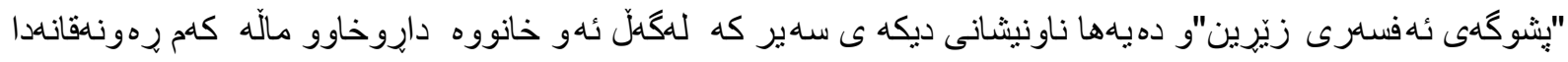

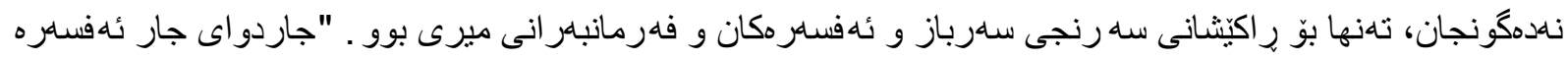

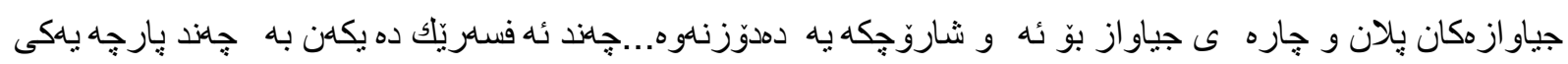

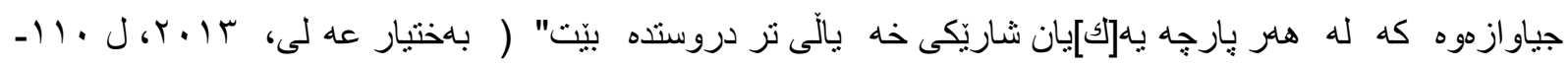

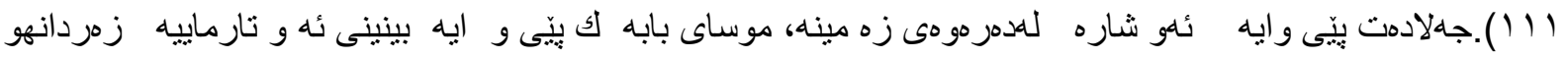

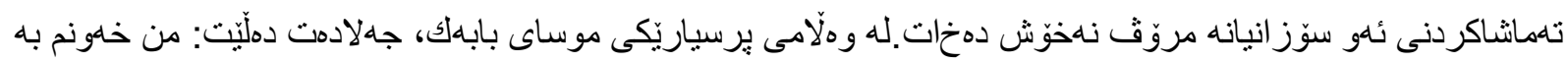

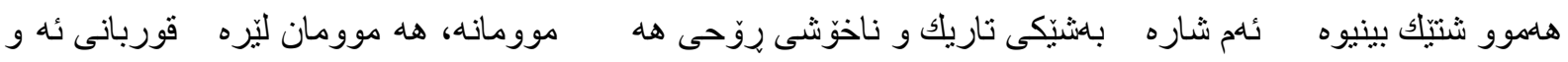

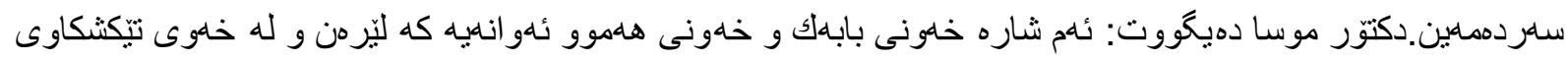

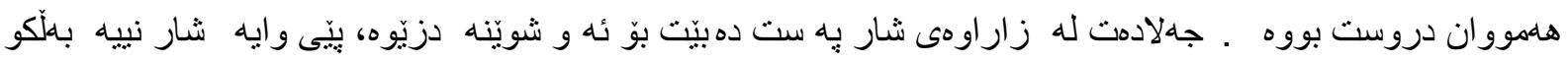

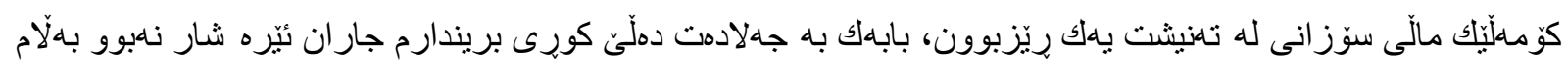

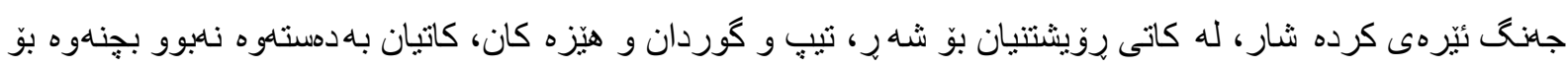

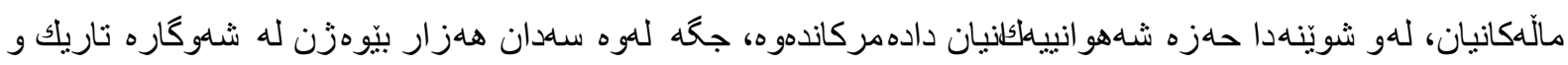

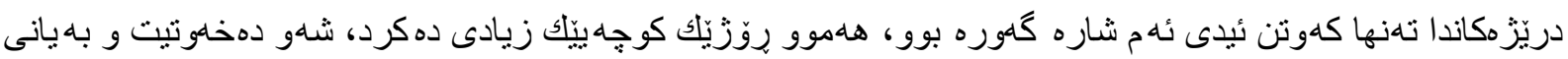

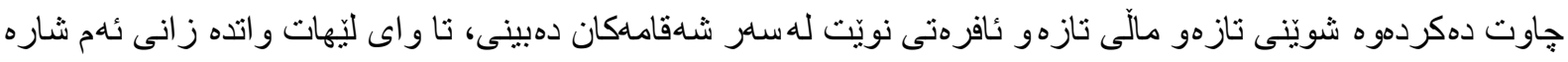

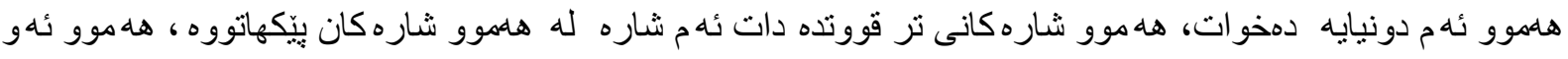

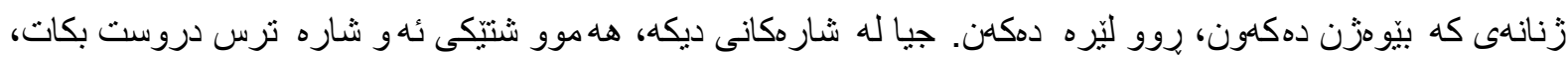

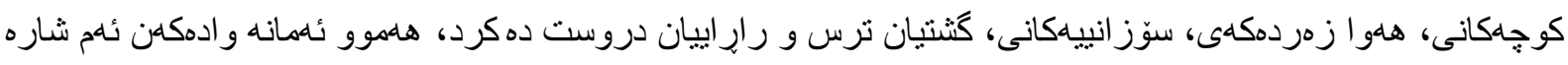

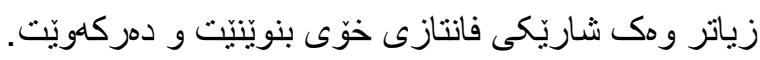

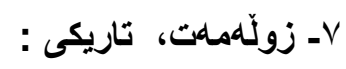

تاريكى زياتر وهى فهز ايهك و ايه، بهلّا م ئهم فهز ايه به جوّريّكه جهلادهت تيايدا دميان شويَن دمبينيّت،

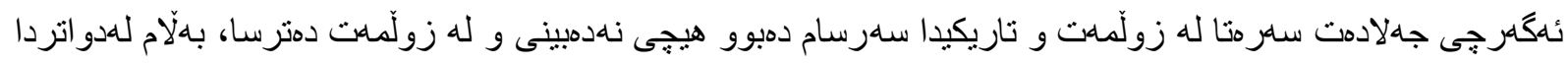




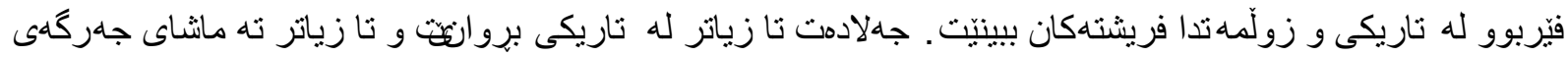

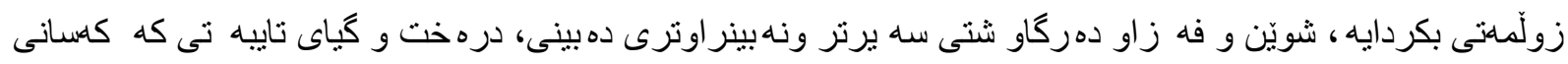

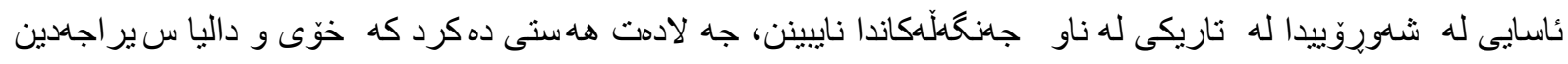

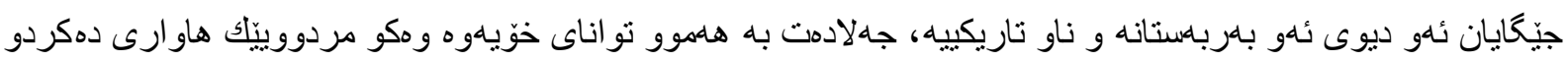

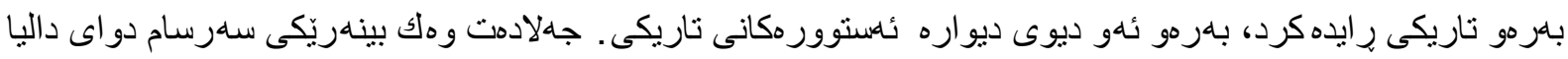

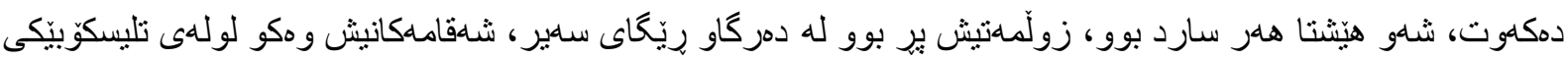

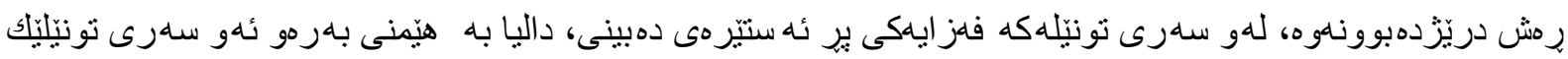

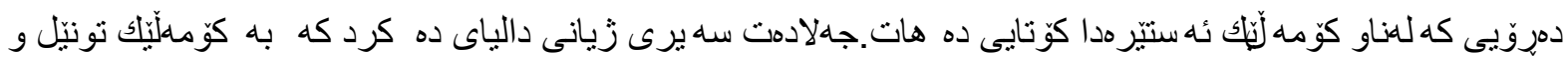

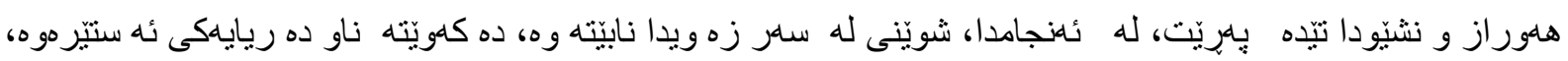

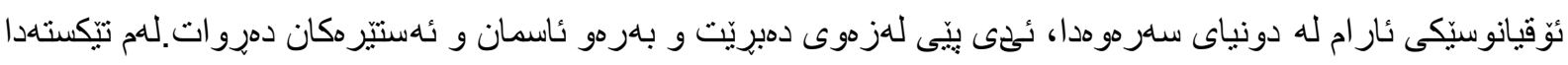

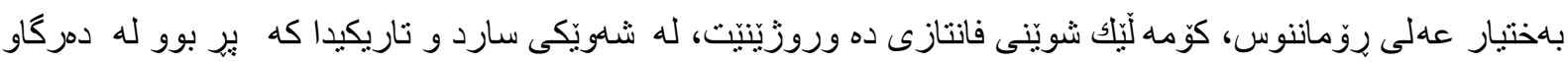

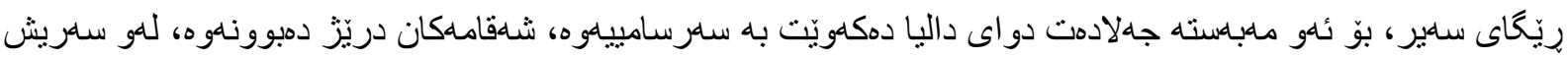

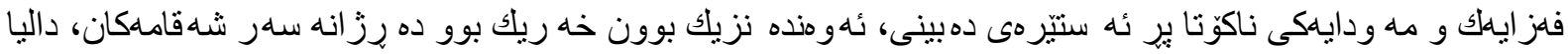

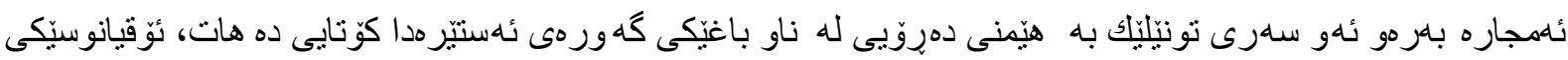

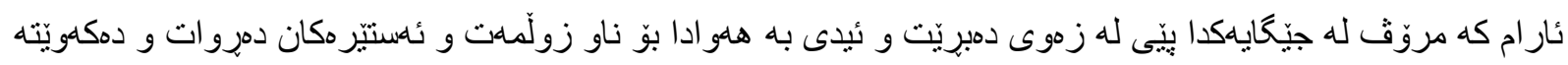
ناو جيهانيّكى فانتازييهوه.

\section{1 - ئوَقيانووسى هاوارهكان:}

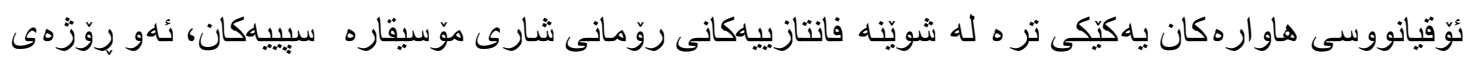

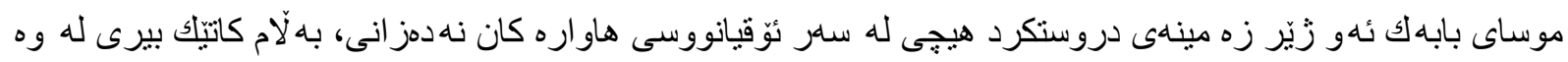

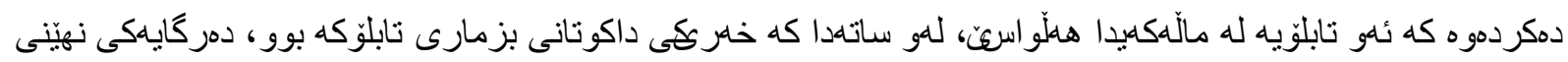

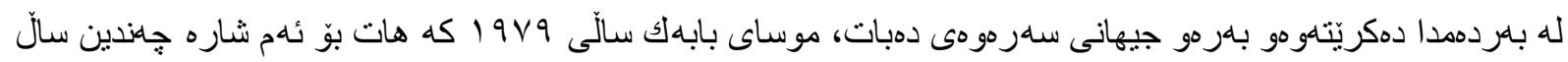

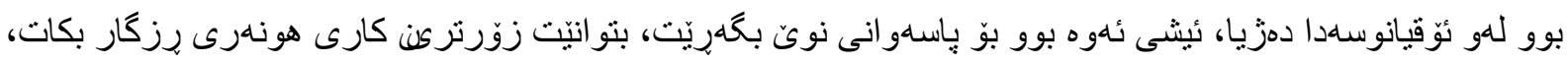

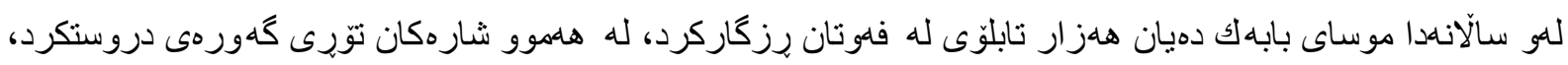

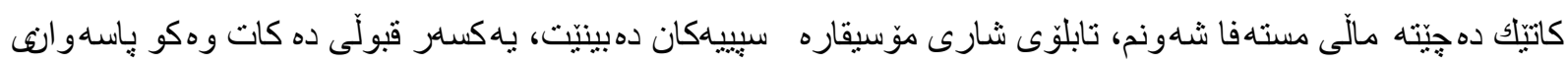

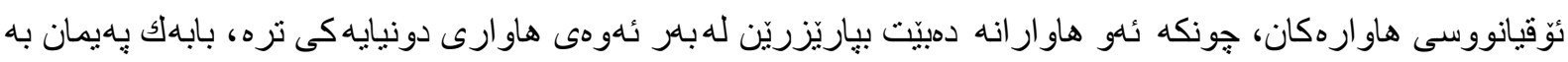

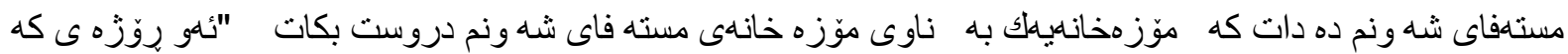

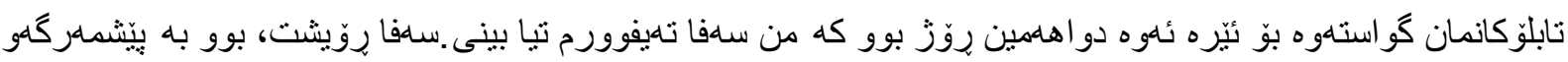

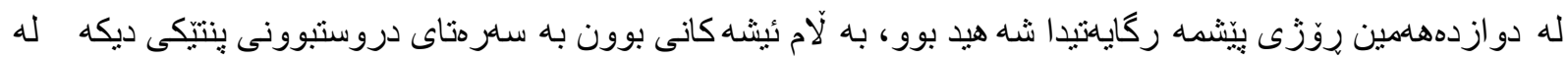

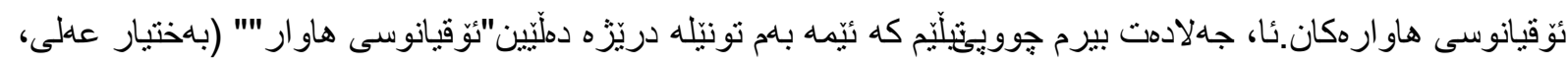

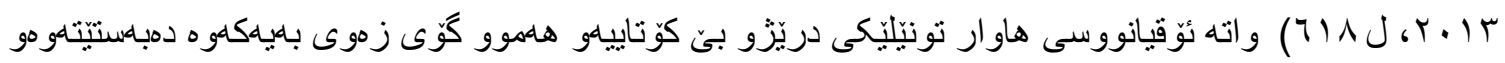

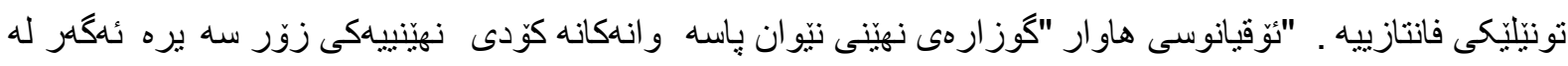

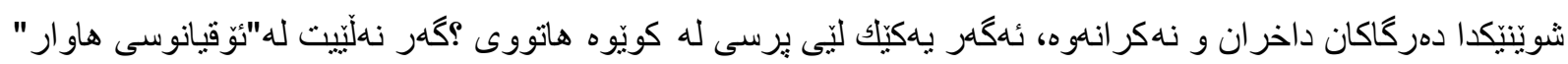

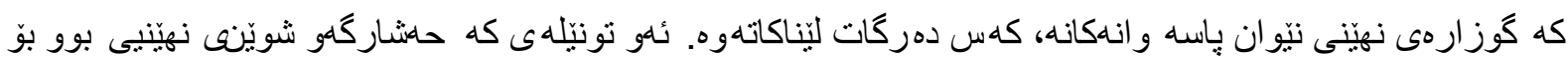

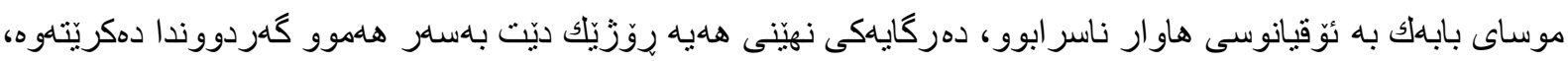




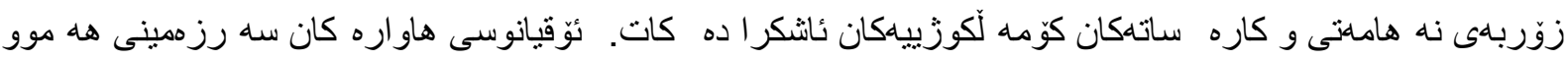

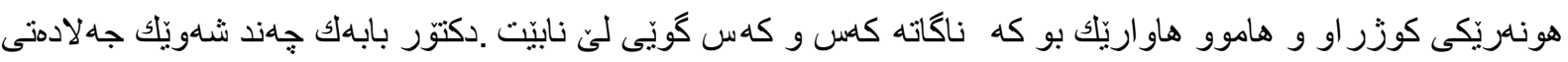

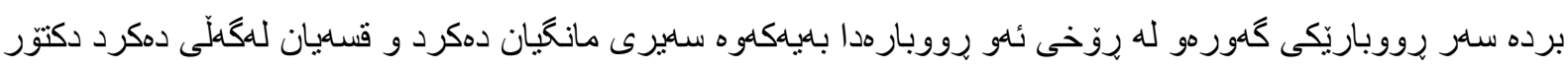

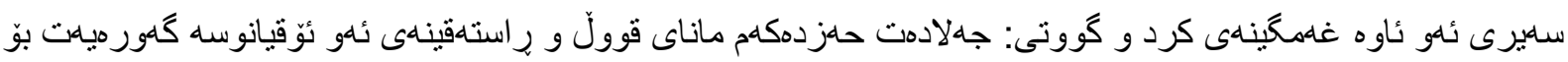

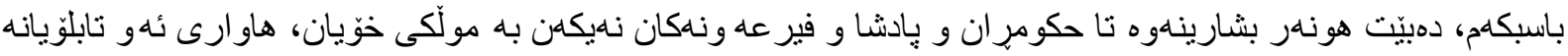

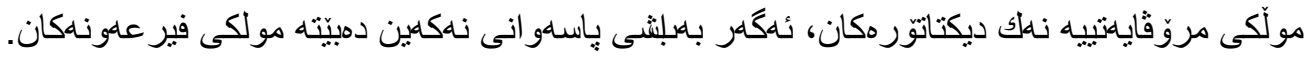

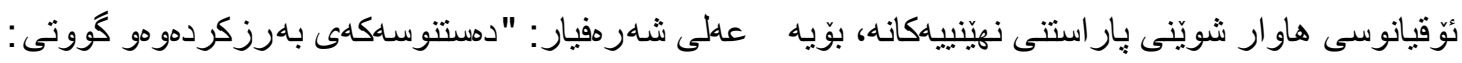

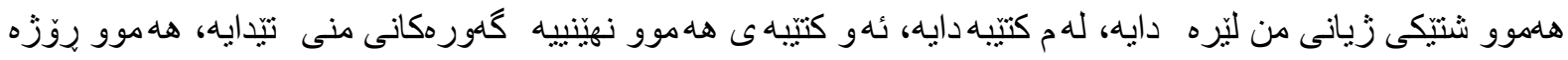

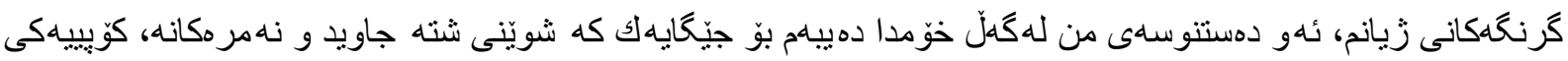

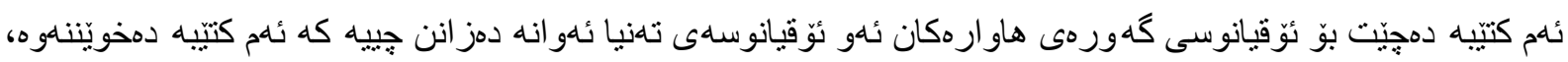

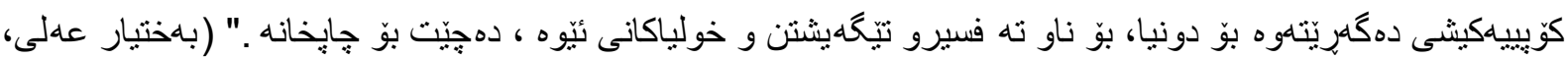

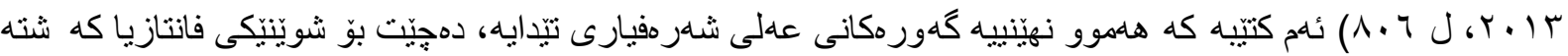

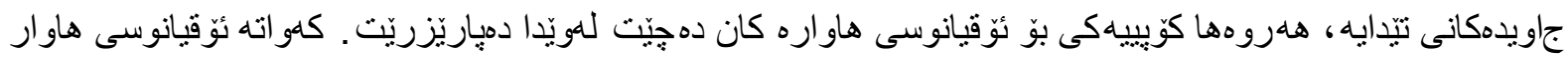

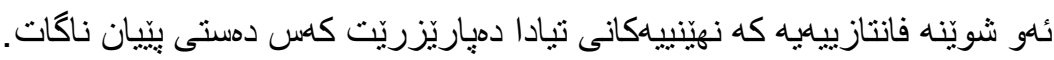

\section{9 - زُيَرزهمينه خورافييهكه، نهيَنيترين موَزهانهى دنيا:}

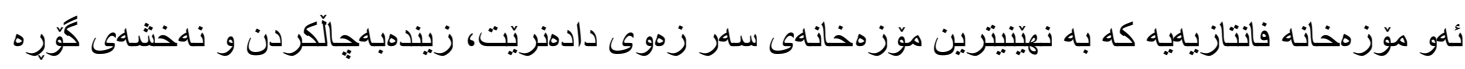

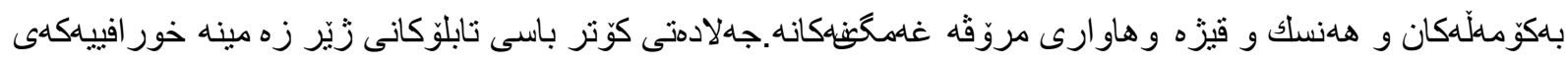

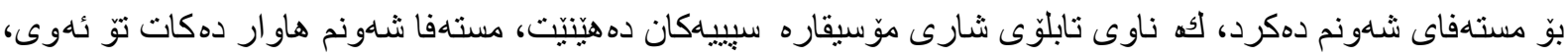

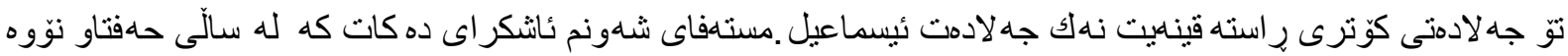

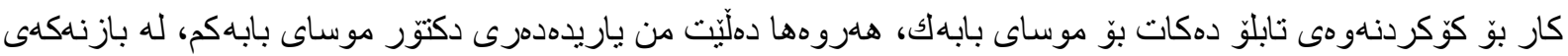

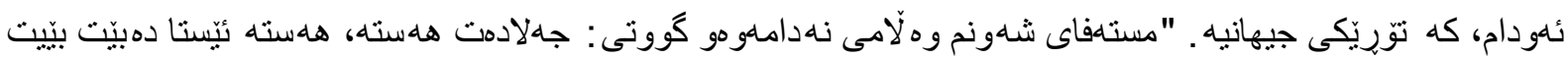

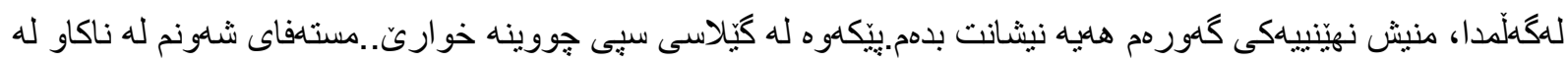

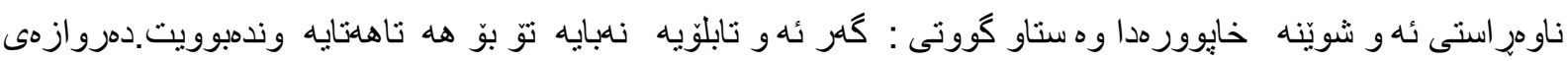

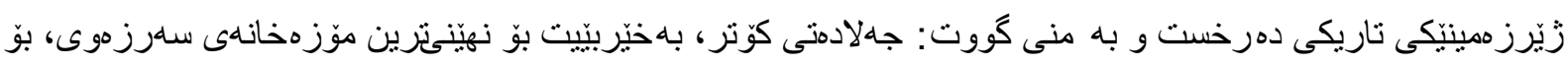

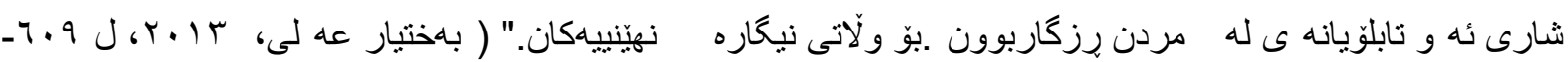

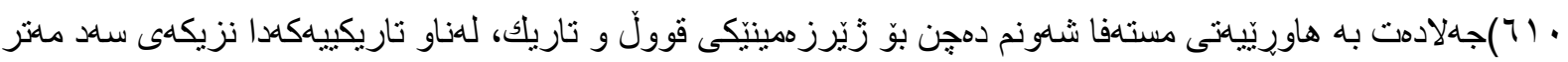

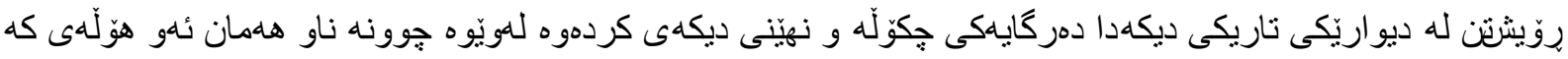

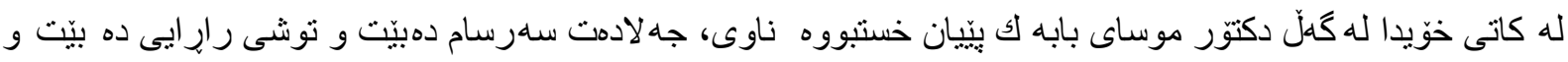

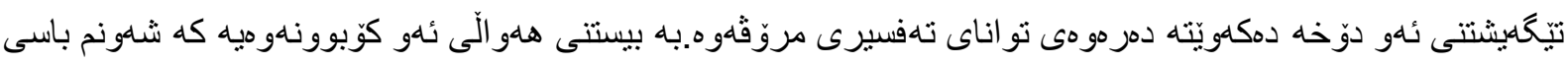

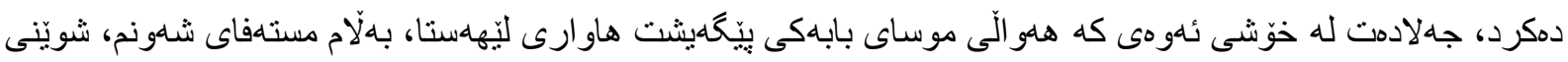

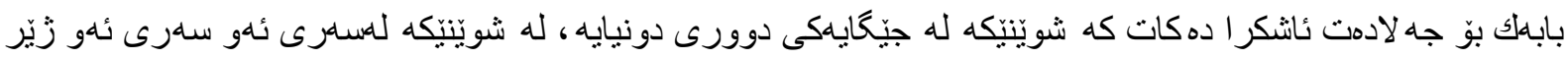

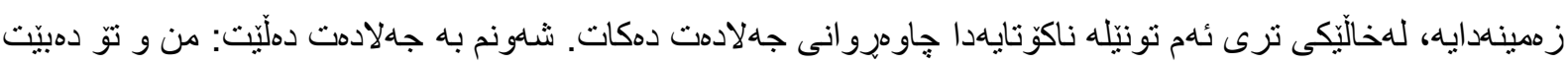

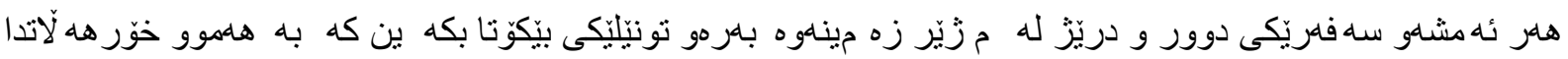

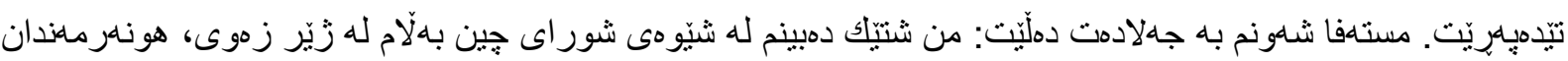




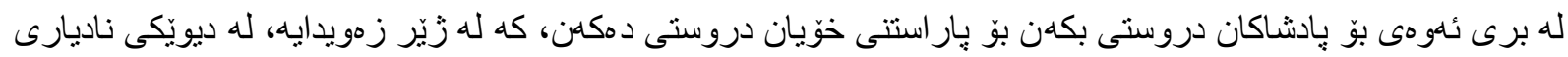

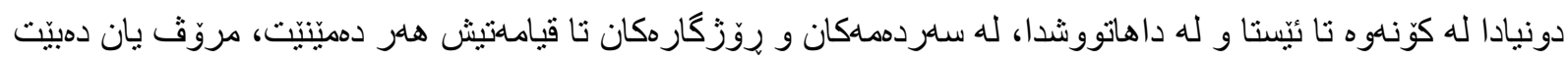

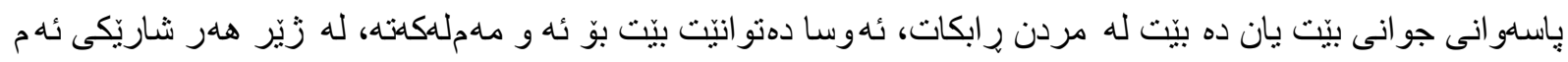

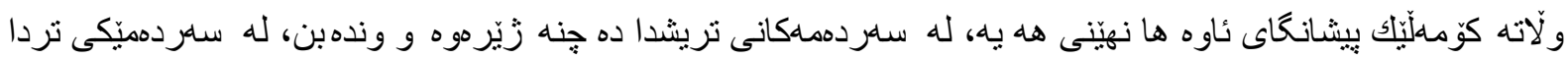

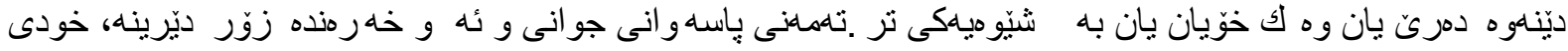

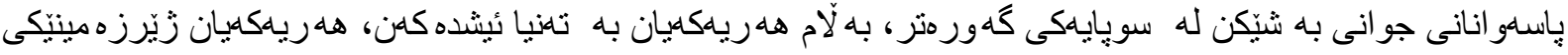

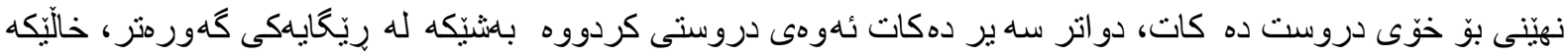

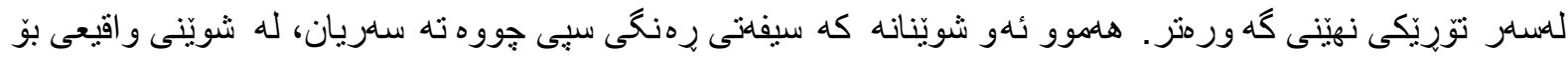

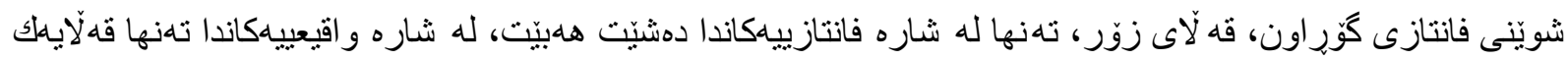

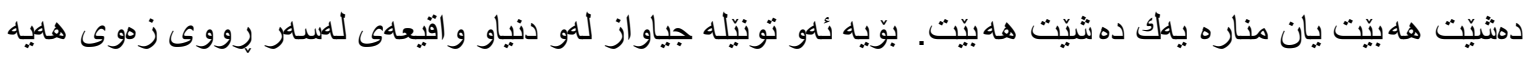

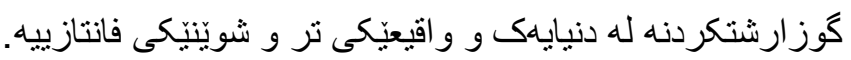

. 1 - شوراى سبيى:

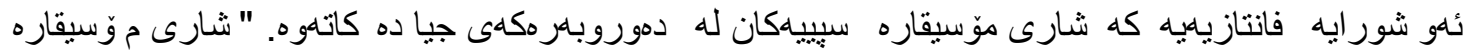

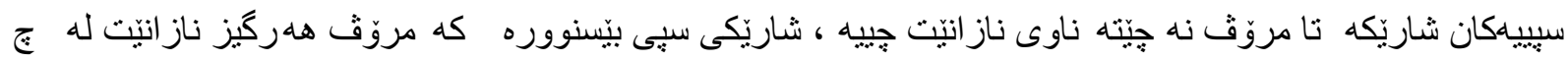

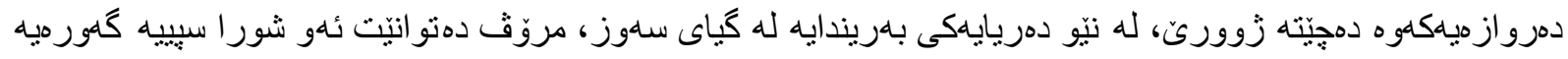

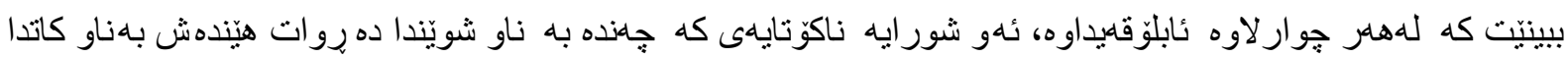

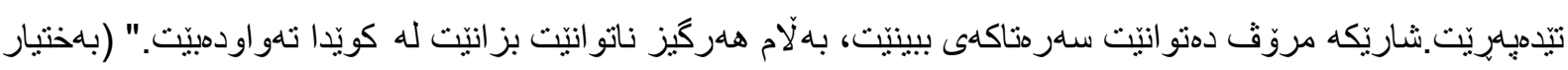

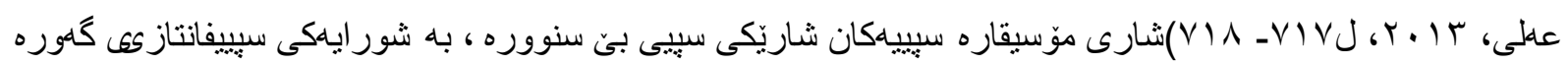

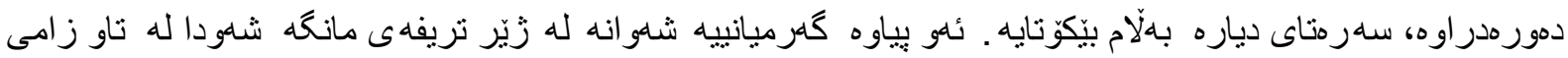

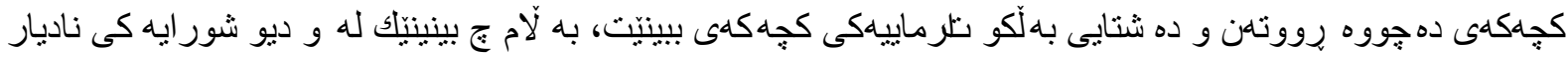

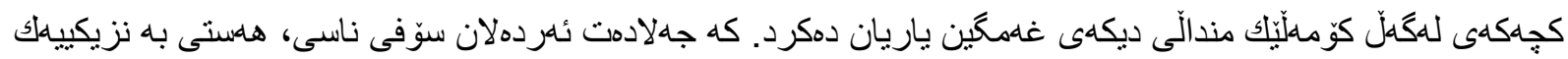

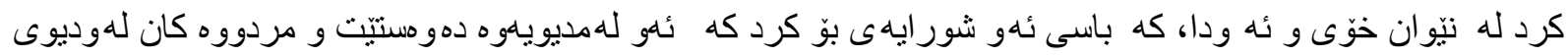

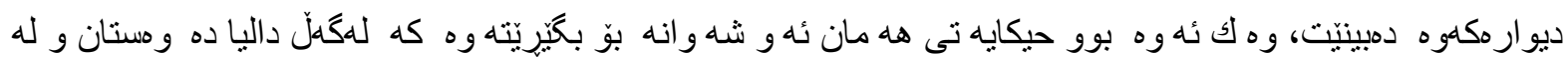

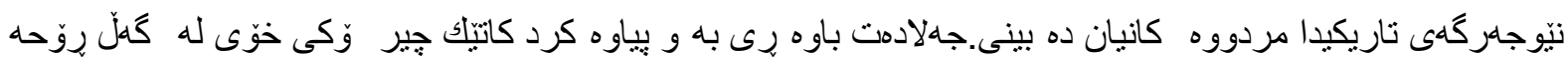

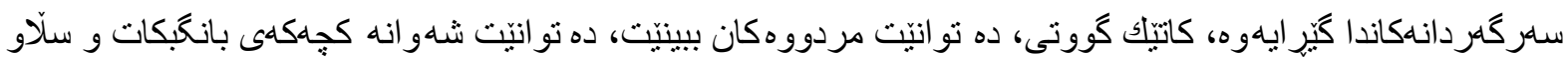

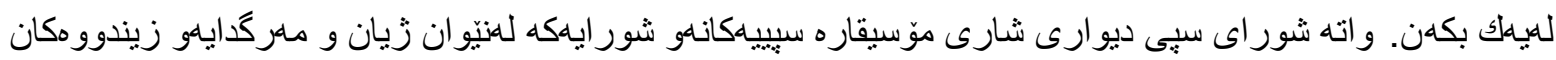

دمتو انن لهو شور ايهوه كاسه مردوو وكانى خوّان بيينن، ئمهاش ئهو شور ايه دهكاته شور ايهكى فانتازى كه له و اقيعدا هاوتاى نييه.

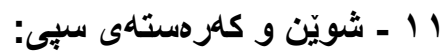

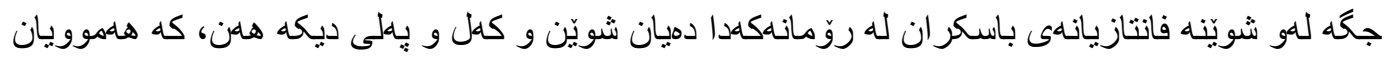

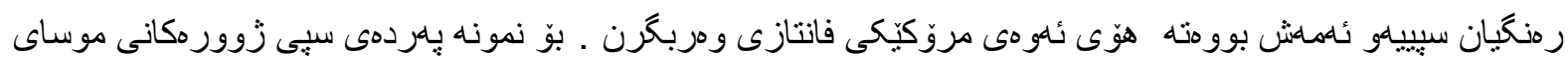

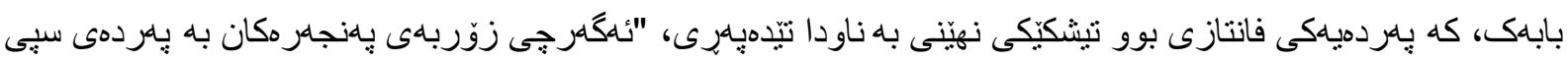

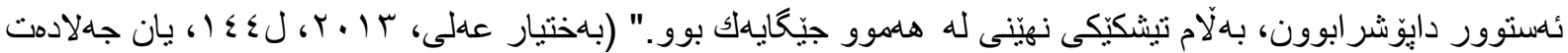

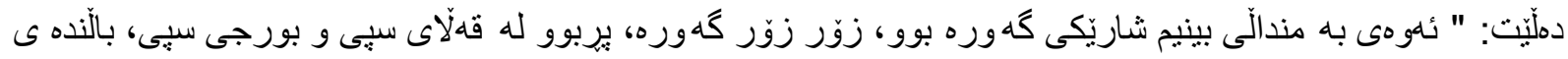




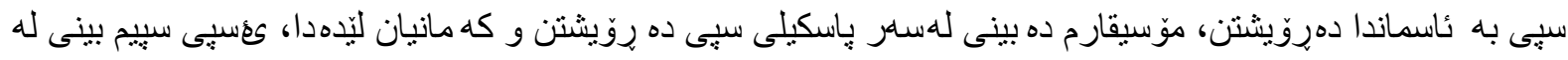

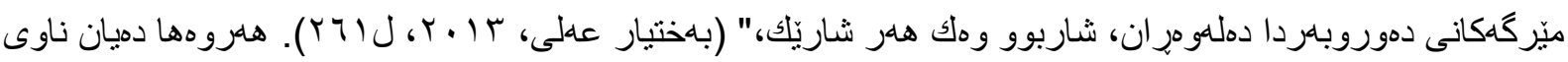

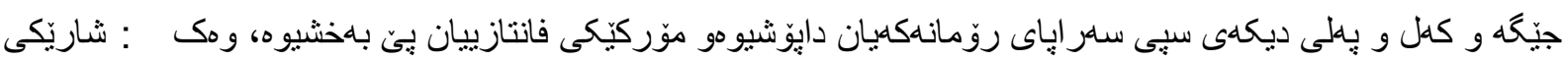

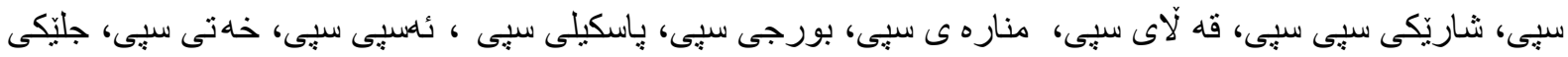

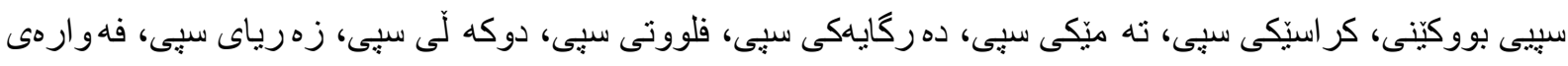

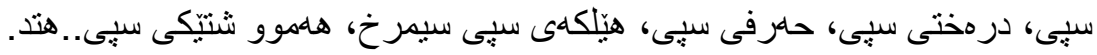

\section{ئسنجام:}

ـ ـناو نيشانى روّمانى شارى موّسيقاره سيبيهكان، ناو نبشانيكى فانتازييه و لله شويّنى فانتازى و كه سينيتيى فانتازى و رووداوى فانتازى بيّكهاتووه.

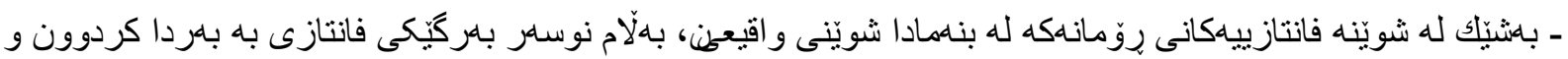
كردوونى به شوينّى فانتازى.

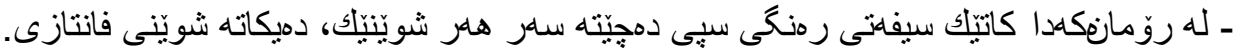

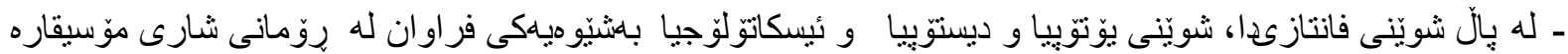

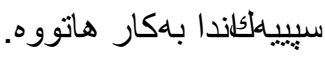

\section{ليستى سدرجاوه كوردياككان:}

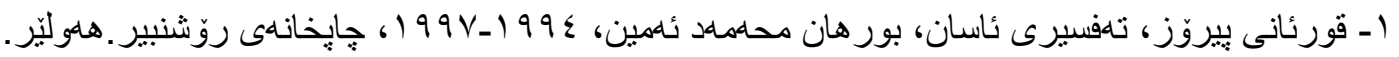

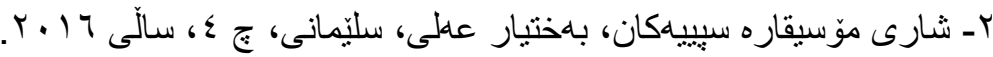

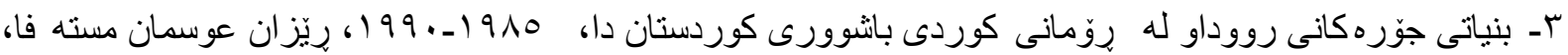

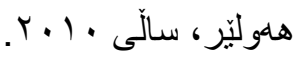

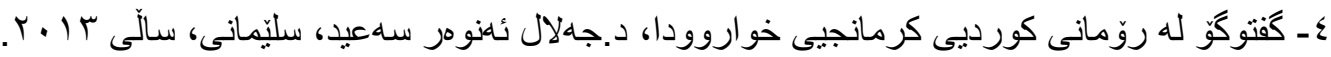

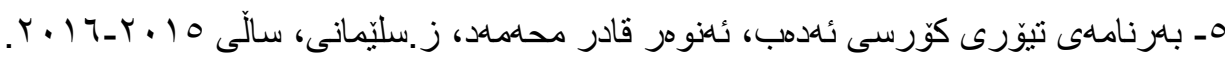

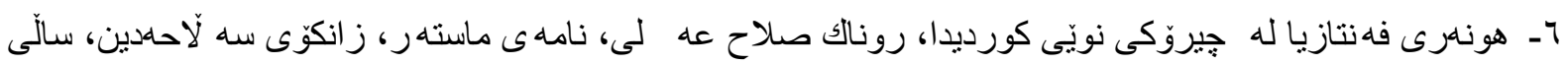
$r \cdot 1 \leq$

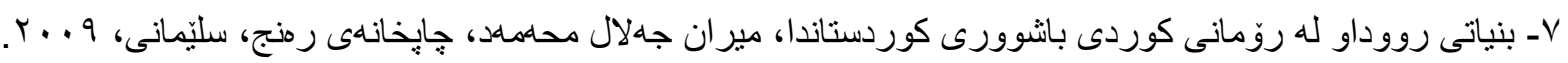

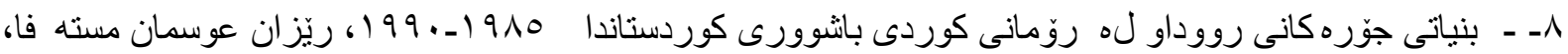

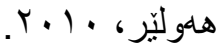

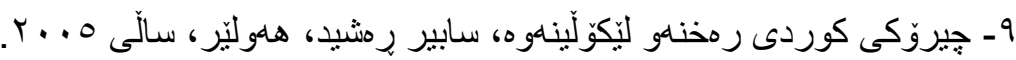

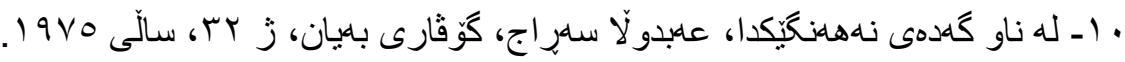

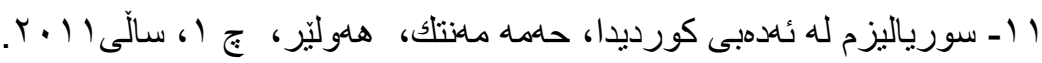

\section{ليستى سمرجاوه علرهبياكان:}

ا ـ العجائبية في ادب الرحلات، رحلة ابن فضلان نموذجا، اشراف د الخامسة علاوي، اعداد الطالب الماجستير عبد

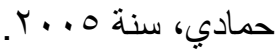

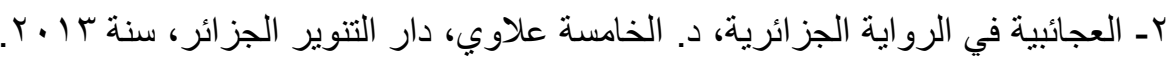




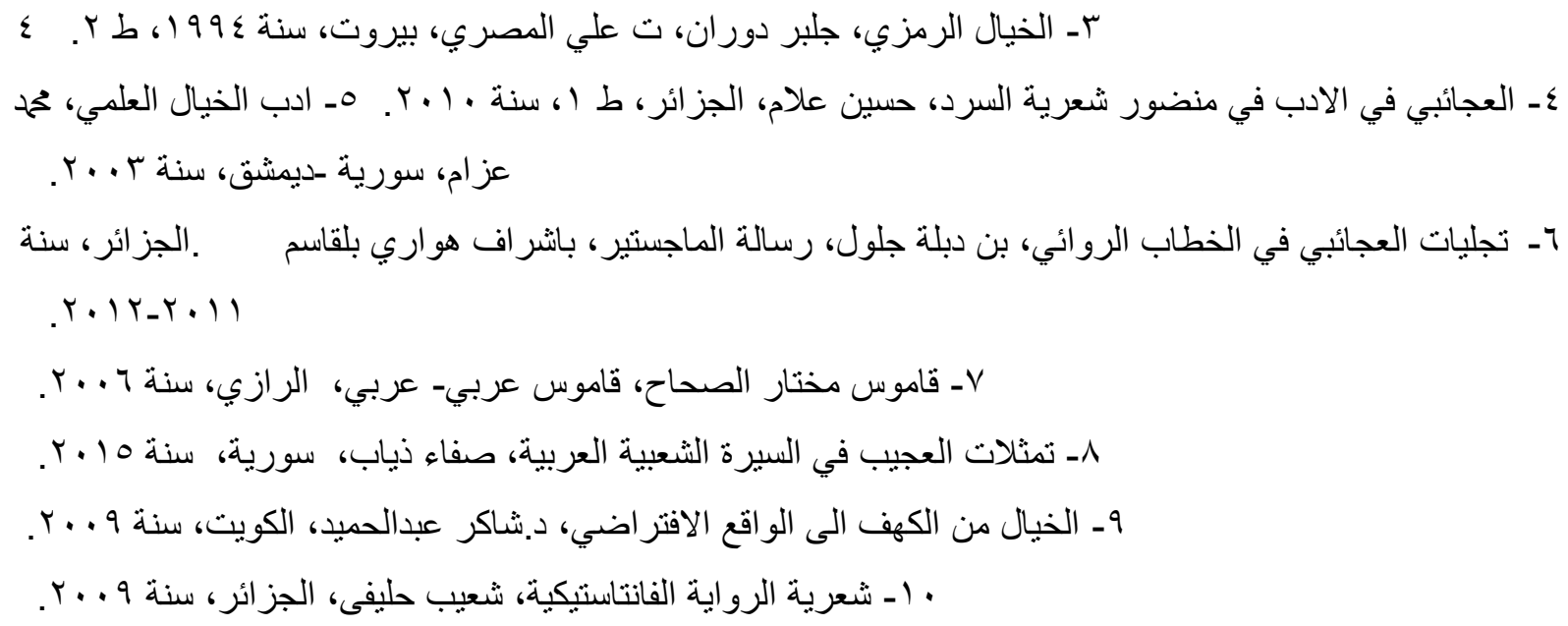

\section{REFERENCES}

Abdul Hamid, Shaker, (2009). Fantasy from the Cave to Virtual Reality, Kuwait.

Ali, Runak Slah, (2014). The art of fantastic in the Kurdish new story, Selahadin University.

Ali, Bakhtyar, (2016). White country musicians.Sulaimania, Fourth Edition.

Allawi, Al Khamse \& Al Hamadi, Abd, (2005). The Wonders of trips literature, the journey of Ibn Fadhlan model.

Allam, Hussein, (2010). Miraculous literature in the narration of narrative poetry, Algeria.

Allawi, Al Khamse (2013). Wonder in the Algerian novel, House of enlightenment Algeria.

Al-Sahah, Mokhtar, (2006). Arabic-Arabic Dictionary, Al-Razi.

Amin, Burhan Muhemmed, The Asan interpret of Quran, Culture Press in Erbil.

Azzam, Mohammad, (2003). Science Fiction literature, Damascus, Syria.

Diab, Safa, (2015). Representations of the strange in the biography of the Arab people, Syria.

Duran, Gelber \& Masri, T. Ali, (1994). Symbolic Fiction, Second Edition 2, Beirut.

Jalul, Ben Debla, (2012). Manifestations in the novelist discourse, Unpublished Master's Thesis, Algeria.

Khalifi, Sha'ab, (2009). The Poetry of the Fantastic Novel, Algeria.

Mentik, Hemed, (2011). Surializim in Kurdish literature, Erbil.

Mohammed, Anwer Qadr, (2015-2016). The theoretical program of literary lessons, Sulaimania.

Mohamed, Miran Jelal, (2009). The basic event in Kurdish novel in south of Kurdistan, Sulaimania.

Mustafa, Rezan Osman, (2010). The basic kind of the event in the Kurdish novel in south of Kurdistan 1985-1990, Erbil.

Rashid, Sabir, (2005). The Kurdish story criticism and research, Erbil.

Saeed, Jelal Anwer, (2013). The dialogue in Kurdish novel in south of Kurdistan, Sulaimania.

Seraj, Abdulla, (1975). In the stomach whale, bayan magazine, No 32. 